Opinion paper

\title{
Environmental impacts of coal subsidies in Turkey: A general equilibrium analysis
}

\author{
Sevil Acar ${ }^{\mathrm{a}}$, A. Erinc Yeldan ${ }^{\mathrm{b}, *}$ \\ a Istanbul Kemerburgaz University, Department of Economics, Istanbul 34217, Turkey \\ ${ }^{\mathrm{b}}$ Bilkent University, Department of Economics, Ankara 06800, Turkey
}

\section{H I G H L I G H T S}

- Turkey supports the coal sector providing both production and investment subsidies.

- Eliminating production subsidies leads to a 2.5\% decline in total CO2(eq) by 2030.

- Additionally, removal of regional investment subsidies reduces CO2(eq) by $5.4 \%$.

- The macro-effects of both scenarios are found to be quite small.

- Coal subsidies could be transferred to the financing of green policy alternatives.

\section{A R T I C L E I N F O}

\section{Article history:}

Received 27 July 2015

Received in revised form

31 October 2015

Accepted 4 December 2015

Available online 17 December 2015

\section{JEL classification:}

C68

044

Q56

Q58

\section{Keywords:}

Coal subsidization

Climate change

Renewable energy sources

Computable general equilibrium

Turkey

\begin{abstract}
A B S T R A C T
In this study we aim at providing an analytical framework for Turkey to study the macroeconomics and environmental impacts of the existing coal subsidization scheme. To this end we develop a regionally differentiated applied general equilibrium model spanning over 2015-2030. Our analytical apparatus focuses exclusively on the fiscal implications as well as the environmental repercussions of the removal of the subsidies on greenhouse gas emissions. With the aid of a set of alternative policy scenarios against a "business as usual" path, we study the regional and sectorial performances of growth, employment, investment and capital accumulation, consumption/welfare and trade balance. Our results indicate that by simple elimination of the coal subsidization scheme, Turkey can reduce its aggregate gaseous emissions by as much as $5 \%$ without a significant loss in its GDP.
\end{abstract}

(c) 2015 Elsevier Ltd. All rights reserved.

\section{Introduction}

As a developing middle-income country, Turkey is facing increased demand for electricity and utilization of primary energy sources. The Ministry of Energy and Natural Resources (MENR) estimates indicate that per capita energy use rose from $1276 \mathrm{kgoe}$ (kilograms of oil equivalent) in 2005 to $1663 \mathrm{kgoe}$ in 2013. Total energy demand currently stands at 135.3 millions toe (tons of oil equivalent). These signal a significant projected expansion of

\footnotetext{
* Corresponding author.

E-mail addresses: sevil.acar@kemerburgaz.edu.tr (S. Acar), yeldane@bilkent.edu.tr (A.E. Yeldan).
}

energy demand in the next decade. Official figures project substantial pressures for continued increase in energy demand, with installed capacity expected to grow from $64 \mathrm{GW}$ in 2014 to approximately $120 \mathrm{GW}$ in 2023 (Acar et al., 2015). The implication of these expectations is that Turkey has not attained stability with respect to its energy demand per capita. Supporting the expected level of growth in demand is in itself a challenge, requiring significant investments in generation capacity and energy infrastructure, as well as continuation of the energy market reforms initiated in the 2000s. However, Turkey is also grappling with the challenges of ensuring a cost-competitive energy supply for its population and the industrial sectors, attaining energy security, and realizing emissions reduction. 
Our proposed analysis looks at how current policy meets these challenges, focusing on plans for expansion of coal-fired power and renewable energy generation, and asking what role the existing coal subsidies play in the broad policy mix. Available rudimentary data reveal that subsidies to coal mining and coal-fired electricity generation amount to 730 million USD in 2013, or 11 USD per MWh of generation (Acar et al., 2015). This corresponds roughly to $0.1 \%$ of the aggregate GDP. By contrast, subsidies to renewable energy sources are dwarfed against the coal subsidization programme.

In this study we investigate the macroeconomic and environmental effects of Turkey's existing coal subsidies using an applied general equilibrium model of the computable general equilibrium (CGE) variety. Prospecting on the 2015-2030 macroeconomic path of the Turkish economy, our analytical apparatus focuses on the direct and indirect incentivization of coal mining, exploration, and power generation. With the aid of a set of alternative policy scenarios against a business as usual path, we evaluate the environmental gains of abatement through the removal of these subsidies, and study the regional and sectorial performances of growth, employment, investment and capital accumulation, consumption/ welfare, trade balance, and emissions.

The paper is organized as follows: as a continuation of this section, we document the extent and characteristics of Turkey's energy policy, the subsidization of coal in particular. In Section 2, we introduce the salient features of the algebraic equations of the CGE model along with the data sources in Section 3. Next, we report and discuss the results of our policy analysis, using the CGE apparatus as a social laboratory in Section 4, while Section 5 concludes.

\subsection{Aspects of Turkey's energy policy and $\mathrm{CO} 2$ emissions}

Turkey has been experiencing a dramatic structural change with respect to its escalated utilization of electricity and primary energy sources. In line with its growing population and GDP, it has been facing increased energy demand in the recent decades. In 2013 , installed electricity capacity reached a level of 64,000 MW, more than 12-times the 1980 capacity level (TEIAS, 2013). The bulk of electricity generation stems from the utilization of fossil fuels, comprised of mainly natural gas and coal. In 2013, gross electricity generation was composed of $44 \%$ natural gas, $27 \%$ hard coal and lignite, $25 \%$ hydro, $3 \%$ wind, and a negligible share of geothermal power. Since the country does not own any significant oil or gas reserves, it is highly dependent on energy imports. IEA (2014) reports that, in 2012, energy imports accounted for more than $80 \%$ of total primary energy supply. Within this composition, $99 \%$ of total gas demand, $93 \%$ of oil and $55 \%$ of coal were imported from various countries.

In order to decrease the reliance on foreign energy sources, ensure energy security, and meet the growing energy demand, Turkey has pursued strong commitment to utilization of all the domestic coal resources, together with its plans to install three nuclear power plants in the near future. On the other hand, the potential of renewable resources such as solar, geothermal, and wind remains hugely untapped in producing energy. The focus on coal has gone so far as to announce the year 2012 as "the year of coal". In all the ten-year development plans as well as strategy documents of the Ministry of Energy and Natural Resources (MENR), boosting coal mining and coal-fired electricity generation appears to be among the priorities of the country, with a strong emphasis on the need to increase investments, extend exploration and rehabilitation budgets, and introduce new incentives to the coal sector. For instance, in the 2015-2019 Strategic Plan of the MENR, coal resources are targeted to be utilized to the most efficient extent possible and generation of electricity from domestic coal is aimed to reach an annual level of 60 billion kWh by the end of the plan period. In order to attain these targets, investments in the sector will be accelerated and new reserves will have to be explored. Similarly, in the Tenth Development Plan, the desire to intensify the efforts to explore new lignite reserves (as well as oil and gas) is repeated. As part of the program, available coal fields that are ready to be operated will be transferred to the private sector via the "royalty tender system", public coal-fired power plants will be rehabilitated and investments to build new coalfired power plants will be facilitated (p. 196).

Coal is still a widely used energy source in the international arena. Data from IEA (2014) reveal that the share of coal in world electricity production rose from $37.4 \%$ in 1990 to $40.3 \%$ in 2012 . Some of this production owes to the availability of generous subsidies provided by governments to the coal sector in many countries. These subsidies are usually designed in order to lower the cost of coal-fired electricity production, increase the price received by energy producers, or decrease the price paid by energy consumers. They take several forms ranging from direct financial transfers and tax exemptions to market price support and provision of services below market rates (provision of land, water, infrastructure, permissions, etc.) based on the WTO definition (WTO, 1994). The cost of fossil fuel subsidies, covering oil, gas and coal subsidies, globally totalled US\$ 548 billion, which was four times more than renewable energy subsidies in 2013 according to IEA (2014).

Fossil fuel subsidies in Turkey are mainly comprised of coal subsidies. The most substantial of producer subsidies to coal is direct transfers from the Undersecretariat of Treasury to the hard coal sector in the form of capital and duty loss payments. These transfers are provided with the aims of subsidizing local employment in the hard coal mining regions and amounted up to around US\$ 300 million in 2013. Besides, the government supports the coal sector with R\&D expenditures, funding for the rehabilitation of hard coal mines and coal power stations, exploration budgets, funding of new coal power plants and investment guarantees to some coal power plants as well as distribution of free coal to poor families as part of its social policy program. Yet, some of the support measures remain unquantifiable since they are not purely financial transfer mechanisms. For instance, exemptions from environmental regulation including temporary exemptions for existing coal plants and permissive environmental impact assessment procedures enable most of the coal projects to be implemented although they are harmful to the environment (Acar et al., 2015, pp. 8-11). Furthermore, Turkey introduced a new investment incentive scheme in 2012, which is comprised of various instruments, ranging from VAT and customs duty exemption, income or corporate tax reduction to social security premium support to the employer, interest support and land allocation. Defined as "priority areas", new coal mining and power generation projects are subsidized within the regional investment incentive scheme with the most generous measures of Regions V and VI.

Using the data for quantifiable incentives in 2013, Acar et al. (2015) estimate a producer subsidy for coal of around US\$0.01 per $\mathrm{kWh}$, which increases to US\$0.02 per kWh when coal aid to consumers is included. In 2013, total amount of subsidies to the coal sector reached $0.1 \%$ of GDP. Needless to say, these figures serve as an underestimate of the total subsidy amount since they do not cover incentives such as investment guarantees, ease of access to credit, exemption from value-added tax and import duties (within the regional investment incentive scheme), or any of the other subsidies identified, which are expected to be significant. Moreover, based purely on production costs, coal is currently only marginally cheaper than onshore wind and significantly cheaper than solar PV. Yet, adding the identified subsidies and the external costs (such as health and environmental damages), coal becomes 
more expensive than the alternative renewables such as wind and solar power (Acar et al., 2015). It has to be noted that this assessment is still based on highly incomplete data on coal subsidies and the failure to estimate full social costs of coal. Extending the analysis to include the dynamic effects towards 2030, a recent report by the WWF-Turkey together with Bloomberg New Energy Finance (BNEF, 2014) argues that accounting for decreases in financial costs of renewable technologies and associated declines in subsidies; both solar PV and wind will likely become much cheaper than coal-fired power generation in Turkey. Estimates from various scientific reports (see e.g. Fraunhofer ISE, 2013) confirm that coal power will remain behind renewable energy technologies as an expensive technology, whereas renewable technologies are expected to get cheaper in the next few decades. However, taking advantage of this fall in costs is likely to prove difficult if the energy sector has already configured its technical and institutional structure to support coal-fired generation, and where financial support to the coal industry has become part of the established status quo. This may lead to the danger of, what is termed by Aghion and others, as path dependence; that is, firms might be "locked" in dirty technologies. Given the distorted price signals, firms with a history of dirty innovations may be further led to innovate towards maintaining dirty technologies and creating path-dependence in the long run (Aghion, 2014).

As a natural consequence of its energy and subsidy policy, Turkey is simultaneously grappling with the challenge of combating climate change. Although the country does not contribute much to the global level of emissions (around 1\% of the world's greenhouse gas (GHG) emissions according to UNFCCC, 2013), it experiences the fastest increase in GHG emissions with respect to its counterparts in the OECD. Aggregate $\mathrm{CO} 2$ emissions have increased by 2.8 times since 1990 , reaching a level of 403.55 million tons of $\mathrm{CO} 2$ (eq) in 2010. Fig. 1 demonstrates that over half of these emissions arise from energy combustion, followed by industrial processes, household waste and agriculture respectively. The fact that energy combustion in electricity production releases the highest amount of emissions is because electricity is mainly generated from fossil fuels. Among various industries, cement and iron and steel sectors are the most emission-intensive ones.

These figures reveal that the structure of the current energy and industrial sectors and the existing coal subsidies in Turkey exacerbate the climate change problem triggering higher levels of
GHG emissions. As a result of the rapid increase in energy supply embodying a coal-biased composition, the already high rate of increase in emissions will likely to get even worse.

To test this hypothesis, we make use of an applied CGE model. We study the economic and environmental impacts of the current coal subsidy scheme and test various scenarios for the impact of the removal of these subsidies.

\section{Methodology: the analytical model}

The model is composed of 12 production sectors spanned over two regionalization bodies for the Turkish economy as High versus Low Income; a representative private household to carry out savings-consumption decisions; a government to implement public policies towards environmental abatement; and a "rest of the world" account to resolve balance of payments transactions. Antecedents of the model rest on the seminal contributions of the CGE analyses on gaseous pollutants, energy utilization, and economics of climate change for Turkey as narrated in Lise (2006), Kumbaroglu (2003), Sahin (2004), Vural (2009), and Telli et al. (2008), Akin-Olcum and Yeldan (2013) Voyvoda and Yeldan (2011) and Bouzaher et al. (2015). All these, however, were based on national aggregates. Yet, given the official focus on regional investment and subsidization programme of Turkey, we find it pertinent to work with a regional diversification. Such an exercise was implemented in Yeldan et al. $(2013,2014)$ in the context of duality of middle income versus poverty traps of the Turkish socioeconomic structure. Here, we follow their procedure for compilation of data at the regional level. More details of this procedure are narrated in Section 3.

\subsection{Commodity structure and regional commodity markets}

In this modeling attempt, in the absence of an official regional $\mathrm{I} /$ O data, we follow the procedure of Yeldan et al. $(2013,2014)$ in setting a regional differentiation of the components of final demand. Aggregate national accounts are decomposed into two regions: High and Low Income. Based on this decomposition, we generate a "final good aggregate" in macroeconomic demand based on product differentiation and imperfect substitution a la Armington (1969). The Armingtonian composite good structure is

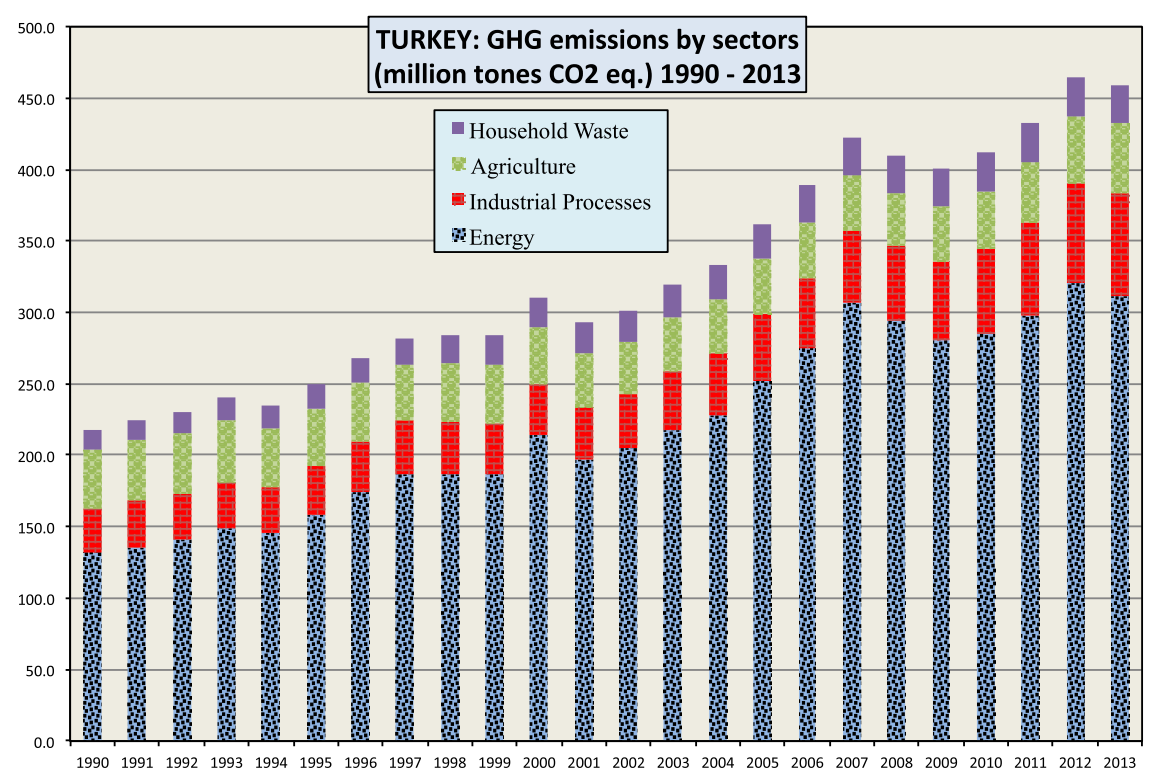

Fig. 1. GHG emissions by sectors (million tons of CO2 eq.) 1990-2013. Source: TurkStat. 
Table 1

Distribution of $\mathrm{CO} 2$ emissions from sectoral production activities by source of origin. Source: Adopted from energy balances tables, min of energy and natural resources.

\begin{tabular}{lllll}
\hline & Sector & $\begin{array}{l}\text { Industrial } \\
\text { processe }\end{array}$ & $\begin{array}{l}\text { Primary energy } \\
\text { utilization }\end{array}$ & $\begin{array}{l}\text { Secondary en- } \\
\text { ergy utilization }\end{array}$ \\
\hline AG & Agriculture & 0.00 & 0.00 & 1.00 \\
CO & Coal & 0.00 & 0.30 & 0.70 \\
PG & Crude Oil and & 0.00 & 0.80 & 0.20 \\
& Natural Gas & & & \\
PE & Refined Petroleum & 0.00 & 0.88 & 0.12 \\
CE & Cement & 0.66 & 0.16 & 0.18 \\
IS & Iron and Steel & 0.67 & 0.15 & 0.18 \\
MW & Machinery and & 0.00 & 0.00 & 1.00 \\
& White Goods & & & \\
ET & Electronics & 0.00 & 0.75 & 0.25 \\
AU & Auto Industry & 0.00 & 0.30 & 0.70 \\
EL & Electricity & 0.00 & 1.00 & 0.00 \\
& Production & & & \\
CN & Construction & 0.00 & 0.00 & 1.00 \\
OE & Other Economy & 0.00 & 0.40 & 0.60 \\
\hline
\end{tabular}

utilized in setting the demand for the domestically produced good versus imports of total absorption $\left(Q^{S}+M-X\right)$. We extend this notion across regions, and decompose the sectorial domesticallyproduced good aggregate, $D C_{i}$, into the regional sources as,

$D C_{i}=B C_{i}\left[\gamma_{i} D C_{i, R H}^{-\rho_{i}}+\left(1-\gamma_{i}\right) D C_{i, R L}^{-\rho_{i}}\right]^{-1 / \rho_{i}}$

Thus, $D C_{i, R}(R=R H, R L)$ forms the aggregate domestic good along an imperfect substitution specification of the Armington aggregate. Aggregate composite good (absorption) is then given as a CES aggregation of imports $M_{i}$ and domestic good aggregate $D C_{i}$,
$C C_{i}=A C_{i}\left[\delta_{i} D C_{i}^{-\phi_{i}}+\left(1-\delta_{i}\right) M_{i}^{-\phi_{i}}\right]^{-1 / \phi_{i}}$

On the production side, production activities are differentiated given regional data on production, employment, and exports.

\subsection{Production technology and gaseous pollutants}

In each sector $i$, production of gross output is modelled as a two-stage activity. At the top stage gross output of region $R$, sector $i$ is given by an expanded Cobb-Douglas functional of the form:

$Q_{i, R}^{S}=A_{i, R}\left[K_{i, R}^{\lambda_{K}, i, R} L F_{i, R}^{\lambda_{L F, i, R}} L I_{i, R}^{\lambda_{L I} L, i, R} E_{i, R}^{\lambda_{E, i, R}}\left(\prod_{j \notin C O, P G, E L} I N_{j, i, R}^{\lambda_{I N, j, i, R}}\right)\right]$

In (3), A denotes exogenously determined total factor productivity (TFP) parameter; and $K, L F$, and $L I$ are the physical capital, formal labor and informal (vulnerable) labor, respectively. Each sector uses intermediate inputs $I N_{j, i}$ as derived from the I/O data. The variable $E$ denotes the energy composite aggregate comprised of three environmentally-sensitive activities of energy generation, viz. coal, petroleum and gas, and electricity. At the lower end of the two-stage characterization of sectorial output, this energy composite is determined by a CES function of its components:

$E_{i, R}=A_{i, R}^{E}\left[\varphi_{C O, i, R} I N_{C O, i, R}^{-\mathrm{e}_{i, R}}+\varphi_{P G, i, R} I N_{P G, i, R}^{-\varrho_{i, R}}+\varphi_{E L, i, R} I N_{E L, i, R}^{-\mathrm{e}_{i, R}}\right]^{-1 / \varrho_{i, R}}$

Under the given energy production technology, optimum mix of inputs of $C O, P G$, and $E L$ is determined by equating their marginal rate of technical substitution to their respective (input) prices, as to be affected by possible fiscal policy:

Table 2

Input-output Table, 2010 (at basic prices) (Millions TL).

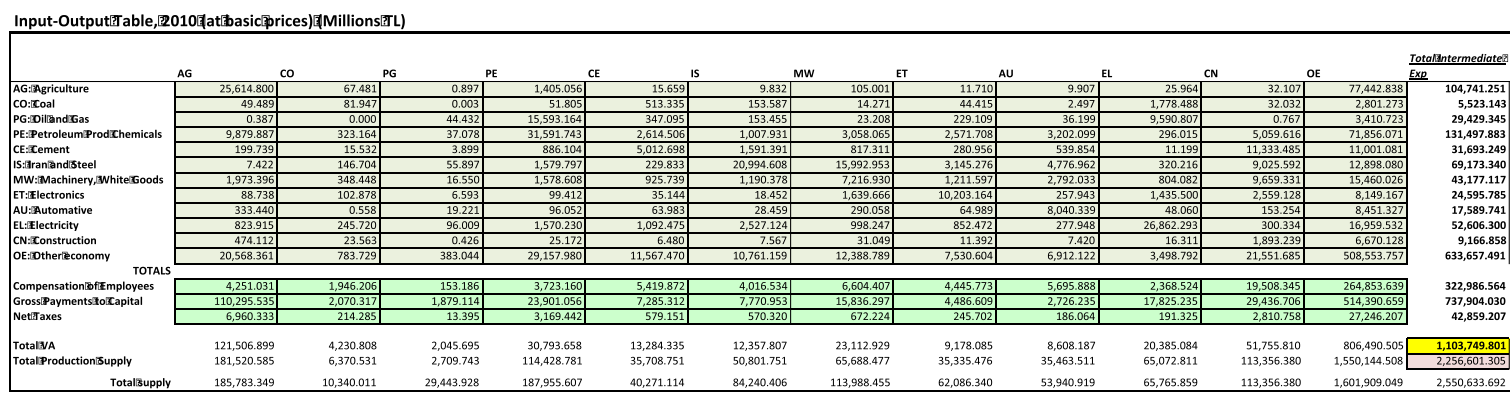

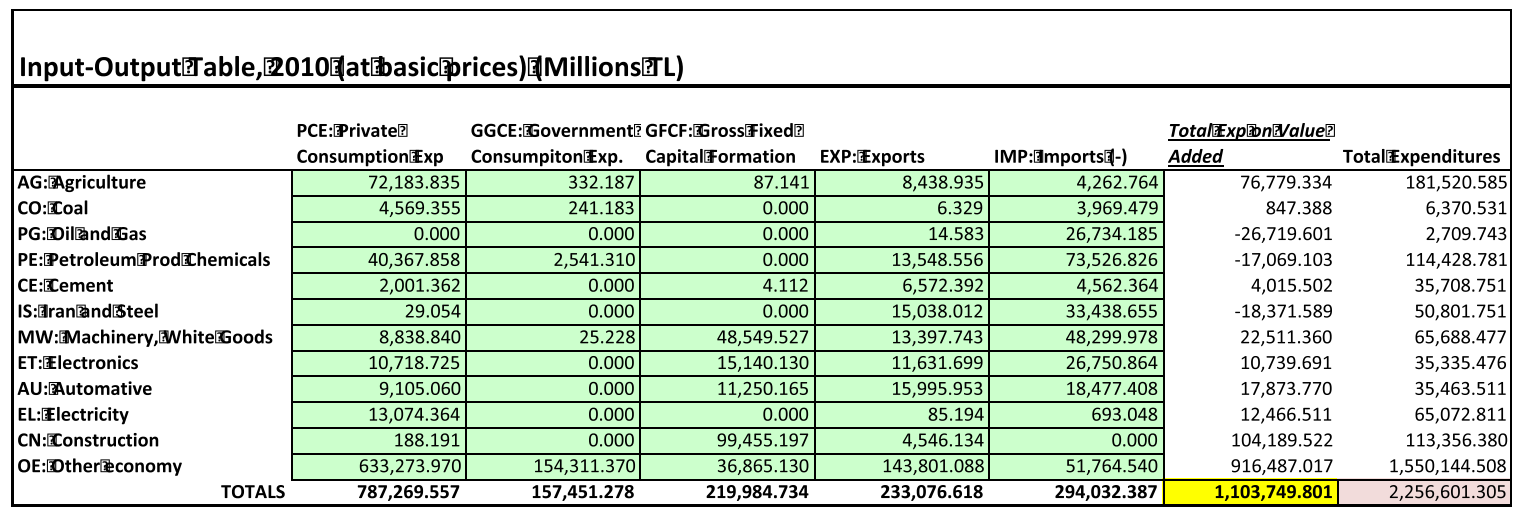


Table 3

Economic indicators across regions (Bill TL, 2010). Source: TurkStat

\begin{tabular}{|c|c|c|c|c|c|c|}
\hline Region & Population (Millions) & Gross regional value added & Regional exports & Regional imports & Tax revenues & Public investment \\
\hline High-income (1) & 40.43 & 745.40 & 83.27 & 111.71 & 130.62 & $12,399.20$ \\
\hline Low-income (2) & 33.31 & 355.30 & 18.87 & 29.22 & 40.70 & $10,318.78$ \\
\hline
\end{tabular}

(1) High income region: TR10, TR21, TR31, TR41, TR42, TR51, TR61

(2) Low-income region: TR62, TR63, TR71, TR72, TR81, TR82, TR83, TR90,TR52, TR32, TR33, TR22, TRA1, TRA2, TRB1, TRB2, TRC1, TRC2, TRC3

Note: HIGH income versus POOR Turkey is partitioned using Turkey average per capita income as the cut off.

Table 4

Aggregate CO2 (Eq) emissions, 2010, millions tons.

\begin{tabular}{lll}
\hline Total CO2 emissions from energy combustion: & $\mathbf{2 2 6 . 9 8}$ \\
\hline AG & Agriculture & 13.69 \\
CO & Coal & 2.57 \\
PG & Crude Oil and Natural Gas & 13.86 \\
PE & Refined Petroleum & 5.58 \\
CE & Cement & 16.36 \\
IS & Iron and Steel & 8.27 \\
MW & Machinery and White Goods & 1.16 \\
ET & Electronics & 2.08 \\
AU & Auto Industry & 0.07 \\
EL & Electricity Production & 112.41 \\
CN & Construction & 0.02 \\
OE & Other Economy & 50.91 \\
Total CO2 emissions by households & $\mathbf{5 0 . 4 7}$ \\
Total CO2 emissions from industrial processes & $\mathbf{4 9 . 0 6}$ \\
& Cement & 31.74 \\
& Iron and Steel & 17.32 \\
Total CO2 emissions from agri processes & 27.13 \\
Total GHG emissions (CO2 eq) & 85.64 \\
& CH4 & 60.44 \\
& N2O from transportation & 19.48 \\
Total CO2 (eq). & F Gasses & 5.72 \\
\hline & & $\mathbf{4 1 1 . 7 4}$ \\
\hline
\end{tabular}

$\frac{I N_{C O, i, R}}{I N_{E L, i, R}}=\left[\left(\frac{\varphi_{C O, i, R}}{\left(1-\varphi_{C O, i, R}-\varphi_{P G, i, R}\right)}\right)\left(\frac{P_{E L, i, R}}{\left(1+t_{C O, i, R}^{E N V}\right) P_{C O, i, R}}\right)\right]^{\sigma_{i, R}}$

$\frac{I N_{P G, i, R}}{I N_{E L, i, R}}=\left[\left(\frac{\varphi_{P G, i, R}}{\left(1-\varphi_{C O, i, R}-\varphi_{P G, i, R}\right)}\right)\left(\frac{P_{E L, i, R}}{\left(1+t_{P G, i, R}^{E N V}\right) P_{P G, i, R}}\right)\right]^{\sigma_{i, R}}$

where $t^{E N V}$ is the relevant tax instrument on the pollutant activity, and $\sigma$ is the elasticity of substitution with $\sigma=1 /(1+\mathrm{Q})$.

Sectorial demands for capital, labor, and the remaining intermediate inputs follow the conventional optimization rules with equating marginal products with their respective input prices. The production technology for gross output in (3) is of constant returns; thus,

$\lambda_{K, i, R}+\lambda_{L F, i, R}+\lambda_{L I, i, R}+\lambda_{E, i, R}+\sum_{j} \lambda_{I D, j, i, R}=1$

We capture the aggregate $\mathrm{CO} 2$ emissions in each sector (and region) from three sources of origin: primary energy combustion (EE), secondary energy combustion (SE), and industrial processes (IND). In our specification, secondary energy combustion is due to utilization of refined petroleum $(R P)$, and emissions from industrial processes are derived exclusively from iron and steel (IS) and cement $(C E)$. Making use of the aggregate energy material balances data we map each sector's $\mathrm{CO} 2$ emissions to these major sources with the aid of the following summary table:

Depending on the source of origin of the gaseous $\mathrm{CO} 2(e q)$ emissions we specify distinct mechanisms. For capturing emissions from the primary energy combustion activities we set

$C O 2_{j, i, R}^{E E}=\epsilon_{j, i, R} \cdot a_{j, i, R} \cdot Q_{j, i, R}^{S}$

and for the combustion of secondary energy source (refined petroleum) we implement,

$C O 2_{R P, i, R}^{S E}=z_{R P, i, R} \cdot a_{R P, i, R} \cdot Q_{R P, i, R}^{S}$

The parameter $\epsilon_{j, i, R}$ in (8) summarizes the energy use coefficients as calibrated from the Material Energy Balances Tables to set the composition of emissions from primary energy via combustion of coal and petroleum and gas in each sector. The $z_{R P, i, R}$ parameter in (9) similarly narrates the emission coefficient due to combustion of $R P$. The traditional input-output coefficient, $a_{j, i}=I N_{j, i} / Q_{i}^{S}$ is responsive to price signals via optimization on costs, given technology (3). This is in contrast to the traditional CGE analyses where $a_{j, i}$ is typically regarded fixed as in a Leontieff technology.

Emissions from industrial processes are recognized within iron and steel $(I S)$ and cement $(C E)$. These emissions are simply regarded as proportional to respective real output:

$C O 2_{i, R}^{I N D}=\eta_{i, R} Q_{i, R}^{S}, \quad i \in\{I S, C E\}$

Emissions from agricultural processes are similarly set proportional to agricultural gross output. Emissions of non-CO2 gasses ( $\mathrm{CH} 4, \mathrm{~F}$ and $\mathrm{NO} 2$ ) are set proportional to the primary energy combustion activities. Thus, $\mathrm{CO} 2(e q)$ emissions of $\mathrm{CH} 4$ become:

$C O 2_{j, i, R}^{C H 4}=\varepsilon_{j, i, R} \cdot a_{j, i, R} \cdot Q_{i, R}^{S} \quad$ for $j=\{C O, P G\}$

as for $\mathrm{CH} 4$ from waste,

$C O 2_{j, i, R}^{W S T}=\varpi_{j, i, R} \cdot Q_{i, R}^{S}$

Households' demand for energy results in a further source of CO2 (eq) emissions. This is regarded as proportional to the household consumption of basic fuels, viz. coal and refined petroleum. Thus,

$\mathrm{CO}^{\mathrm{HH}}=\sum_{i \in C O, R P} \kappa_{i} C_{i}^{D}$

Aggregate $\mathrm{CO} 2(e q)$ emissions is the sum of each of these sources:

$$
\begin{aligned}
C O 2^{\mathrm{TOT}}= & \sum_{j, i, R}\left(C O 2_{j, i, R}^{E E}+C O 2_{j, i, R}^{S E}+C O 2_{j, i, R}^{C H 4}+C O 2_{j, i, R}^{W S T}\right) \\
& +\sum_{i \in I S, C E} C O 2_{i, R}^{I N D}+\sum_{R} C O 2_{R}^{A G R}+C O 2^{H H}
\end{aligned}
$$

\subsection{Labor markets, income generation and general equilibrium}

We distinguish two types of labor: formal and informal/vulnerable. Based on ILO's specification, ${ }^{1}$, vulnerable employment is

\footnotetext{
${ }^{1}$ ILO, World of Work, various issues, Geneva.
} 


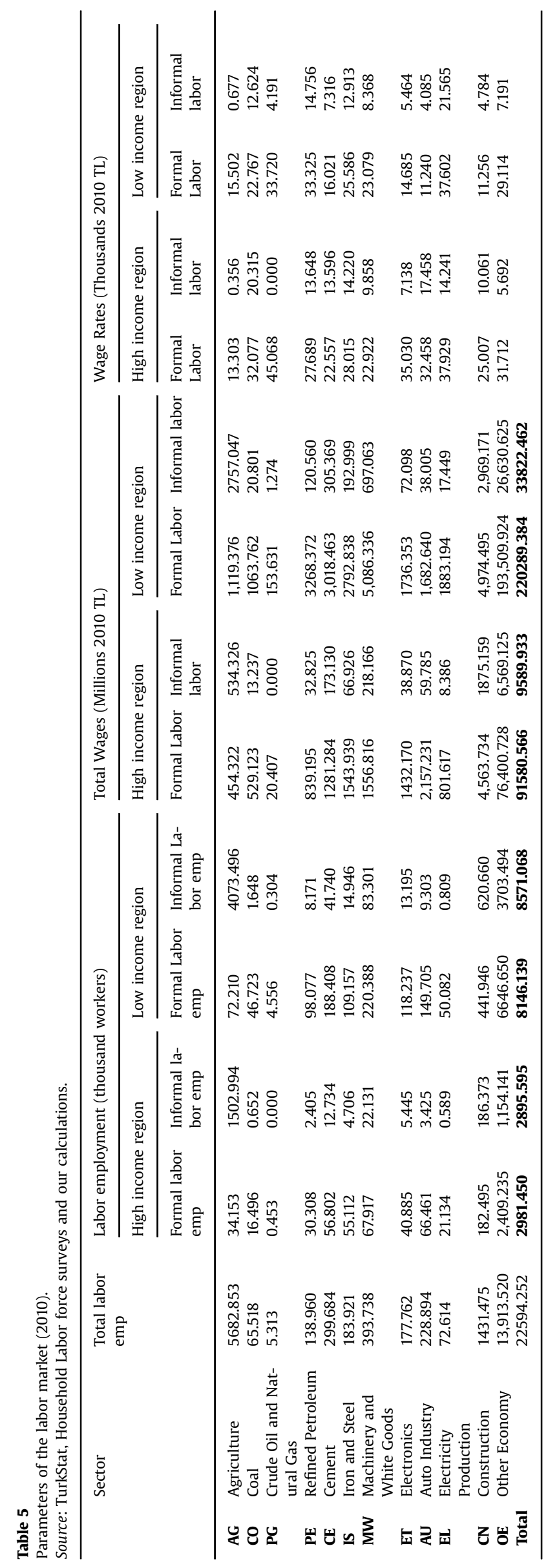

characterized by informal/unregistered employees without any social security coverage; self-employed, and unpaid family workers. The two labor categories obey different labor market characteristics. We set the formal wage rates exogenously given, calibrated above the otherwise market clearing wage rate to generate the level of regional unemployment rates as of 2010. Thus, the formal labor market clears by quantity adjustments on employment,

$U_{L F, R}=L_{L F, R}^{S}-\sum_{i} L F_{i, R}^{D}$

The informal/vulnerable labor market, on the other hand, operates with fully flexible wages. The low level of informal wages is a symptomatic proxy for poverty of vulnerable labor.

Over periods, the regional labor markets are linked by migration. This is based on (expected) wage differences across the high income versus low income Turkey, and is driven along the classic Harris-Todaro (1970) specification. Thus, given the migrants from each labor type, $l=L F, L I$

$M I G_{l}(t)=\mu_{l}\left[\frac{\left(E\left[W_{l, R H}\right]-W_{l, R L}\right)}{W_{l, R L}}\right] L_{l, R L}^{S}$

where $E\left[W_{l, R H}\right]$ is the expected wage rate of labor type- $l(=L F, L I)$ in the high income region, and $\mu_{l}$ is a calibration parameter.

Given $M_{I} G_{l}(t)$, based on wage expectations from region-High, labor supplies evolve according to,

$L_{l, R L}^{S}(t+1)=\left(1+n_{l, R L}\right) L_{l, R L}^{S}(t)-M I G_{l}(t)$

$L_{l, R H}^{S}(t+1)=\left(1+n_{l, R H}\right) L_{l, R H}^{S}(t)+M I G_{l}(t)$

Capital stocks evolve given fixed investments net of depreciation. Allocation of aggregate net investment funds to sectors (investment by sector of destination) is accomplished through the calculus of regional profitability. Given sectorial profit rates, $r_{i, R}$, across region and the economy-wide average profit rate, $r^{A V G}$, sectorial investment allocations, $\Delta K_{i, R}(t+1)$ are given by the following simple rule:

$\Delta K_{i, R}(t+1)=\Pi_{i, R}+\Pi_{i, R}\left[\frac{r_{i, R-r} \text { AVG }}{r_{i, R}}\right]$

where $\Pi_{i, R}$ is the share of aggregate profits in sector $i$, region $R$. This share sets the allocation of physical investments to be reused via differences in profits in the second part of the equation.

Private household income is composed of labor wage incomes and remittances of profits from the enterprise sector. In turn, the public sector revenues comprise tax revenues from wage and capital incomes, and non-tax sources of income from various exogenous flows. The income flow of the public sector is further augmented by indirect taxes and environmental taxes. The model follows the fiscal budget constraints closely. Given public earnings, government's "transfer expenditures to households" is adjusted endogenously to sustain other components of public demand (public investment and consumption expenditures) as fixed ratios to national income.

The general equilibrium of the system is obtained via endogenous solutions on prices, wage rates and the exchange rate. Informal wage rates across regions clear regional labor markets. The balance of payments is cleared through flexible adjustments on the real exchange rate (ratio of domestic good price to imports in the CGE folklore) while the nominal conversion factor across domestic and world prices serving as the numéraire of the system.

The model is solved iteratively by updating of the annual "solutions" of the model up to 2030. Aggregate output supplies grow through three channels: (i) exogenous growth of labor supplies; (ii) investments on physical capital net of depreciation; and (iii) 


\begin{tabular}{|c|c|c|c|c|c|c|c|c|c|c|c|c|}
\hline & \multicolumn{4}{|c|}{ Base path } & \multicolumn{4}{|c|}{$\begin{array}{l}\text { Scenario 1: Eliminate production subsidies } \\
\text { on coal }\end{array}$} & \multicolumn{4}{|c|}{$\begin{array}{l}\text { Scenario 2: Eliminate both production and in- } \\
\text { vestment subsidies on coal }\end{array}$} \\
\hline & 2015 & 2020 & 2025 & 2030 & 2015 & 2020 & 2025 & 2030 & 2015 & 2020 & 2025 & 2030 \\
\hline High income region total supply & 1765.3 & $2,141.9$ & 2572.5 & 3145.3 & 1763.2 & $2,139.2$ & 2569.1 & 3141.0 & 1759.7 & $2,133.8$ & 2561.8 & 3131.2 \\
\hline Low income region total supply & 1055.8 & $1,306.7$ & $1,600.0$ & 1863.9 & 1054.1 & $1,304.5$ & 1597.1 & 1860.6 & 1051.3 & $1,300.5$ & 1591.7 & 1853.7 \\
\hline Total GDP & $1,367.3$ & $1,660.4$ & 1991.9 & $2,371.0$ & $1,365.7$ & $1,658.3$ & 1989.2 & $2,367.7$ & $1,362.4$ & $1,653.4$ & 1982.7 & $2,359.2$ \\
\hline Real rate of growth GDP & 4.6 & 3.7 & 3.3 & 3.5 & 4.6 & 3.7 & 3.3 & 3.5 & 4.6 & 3.7 & 3.3 & 3.4 \\
\hline High income region value added & 680.7 & 818.0 & 981.4 & $1,190.9$ & 679.4 & 816.3 & 979.4 & $1,188.5$ & 677.2 & 813.3 & 975.4 & $1,183.4$ \\
\hline Low income region value added & 425.8 & 515.8 & 625.9 & 739.9 & 424.8 & 514.7 & 624.4 & 738.2 & 423.4 & 512.7 & 621.8 & 734.9 \\
\hline $\begin{array}{l}\text { Formal labor employment in } \\
\text { high income region (Mill } \\
\text { Per) }\end{array}$ & 3.6 & 3.6 & 4.0 & 4.5 & 3.6 & 3.6 & 3.9 & 4.5 & 3.6 & 3.6 & 3.9 & 4.5 \\
\hline $\begin{array}{l}\text { Formal labor employment in low } \\
\text { income region (Mill Per) }\end{array}$ & 8.7 & 10.0 & 11.5 & 12.7 & 8.7 & 10.0 & 11.5 & 12.7 & 8.7 & 10.0 & 11.4 & 12.6 \\
\hline $\begin{array}{l}\text { Formal labor employment, Total } \\
\text { (Mill Per) }\end{array}$ & 12.3 & 13.7 & 15.5 & 17.2 & 12.3 & 13.6 & 15.4 & 17.2 & 12.2 & 13.6 & 15.4 & 17.1 \\
\hline $\begin{array}{l}\text { InFormal labor employment in } \\
\text { high income region (Mill } \\
\text { Per) }\end{array}$ & 2.8 & 2.8 & 3.0 & 3.3 & 2.8 & 2.8 & 3.0 & 3.3 & 2.8 & 2.8 & 3.0 & 3.3 \\
\hline $\begin{array}{l}\text { InFormal labor employment in } \\
\text { low income region (Mill Per) }\end{array}$ & 9.7 & 10.9 & 12.1 & 13.2 & 9.7 & 10.9 & 12.1 & 13.2 & 9.7 & 10.9 & 12.1 & 13.2 \\
\hline $\begin{array}{l}\text { Informal labor employment, To- } \\
\text { tal (Mill Per) }\end{array}$ & 12.5 & 13.7 & 15.1 & 16.5 & 12.5 & 13.7 & 15.1 & 16.5 & 12.5 & 13.7 & 15.1 & 16.5 \\
\hline $\begin{array}{l}\text { Total labor employment (Mill } \\
\quad \text { Per) }\end{array}$ & 24.8 & 27.4 & 30.5 & 33.7 & 24.8 & 27.3 & 30.5 & 33.7 & 24.7 & 27.3 & 30.4 & 33.6 \\
\hline Informal labor migration (1000s) & -21.0 & 9.5 & 19.9 & 44.7 & -21.1 & 9.5 & 19.9 & 44.7 & -21.0 & 9.5 & 19.9 & 44.8 \\
\hline Unemployment rate high income & 8.0 & 8.0 & 8.0 & 7.0 & 8.1 & 8.0 & 8.0 & 7.0 & 8.2 & 8.1 & 8.1 & 7.0 \\
\hline Unemployment rate low income & 12.0 & 11.0 & 9.0 & 8.0 & 12.1 & 11.2 & 9.2 & 8.2 & 12.3 & 11.4 & 9.5 & 8.5 \\
\hline Average unemployment rate & 11.0 & 10.3 & 8.8 & 7.8 & 11.1 & 10.4 & 8.9 & 7.9 & 11.3 & 10.6 & 9.1 & 8.2 \\
\hline Private disposable income & 1053.9 & 1254.4 & 1507.4 & 1806.4 & 1051.9 & 1251.9 & 1504.3 & 1802.7 & 1048.7 & 1247.4 & 1498.3 & 1794.9 \\
\hline Government revenues/GDP & 25.2 & 25.1 & 25.0 & 24.9 & 25.2 & 25.1 & 25.1 & 25.0 & 25.3 & 25.2 & 25.1 & 25.0 \\
\hline PSBR/GDP & -1.1 & 0.3 & 0.3 & 0.2 & -1.1 & 0.3 & 0.3 & 0.2 & -1.1 & 0.3 & 0.3 & 0.2 \\
\hline Aggregate investment & 275.2 & 325.2 & 376.8 & 440.1 & 275.0 & 325.0 & 376.5 & 439.8 & 274.6 & 324.3 & 375.6 & 438.6 \\
\hline Aggregate consumption & 942.7 & $1,129.8$ & $1,349.1$ & 1598.4 & 940.8 & $1,127.5$ & $1,346.2$ & 1594.8 & 937.8 & $1,123.3$ & $1,340.7$ & 1587.7 \\
\hline Private foreign Debt/GDP & 55.6 & 68.3 & 74.9 & 77.5 & 55.6 & 68.4 & 75.0 & 77.6 & 55.7 & 68.5 & 75.2 & 77.8 \\
\hline Government foreign Debt/GDP & 24.6 & 20.4 & 16.9 & 14.0 & 24.6 & 20.4 & 16.9 & 14.0 & 24.7 & 20.5 & 17.0 & 14.1 \\
\hline Government domestic Debt/GDP & 19.6 & 10.8 & 10.4 & 9.9 & 19.6 & 10.8 & 10.4 & 9.9 & 19.7 & 10.9 & 10.5 & 10.0 \\
\hline Current account deficit/GDP & 5.4 & 4.4 & 3.7 & 3.1 & 5.4 & 4.4 & 3.7 & 3.1 & 5.4 & 4.5 & 3.7 & 3.1 \\
\hline
\end{tabular}

total factor productivity (TFP) growth, which in turn is regarded exogenous. In each period, capital stocks across regions and sectors are augmented with net investments. Regional labor supplies are increased exogenously by population growth and the migration process (see Eq. (16)). Technical factor productivity rates are updated in a Hicks-neutral manner. Formal real wage rates are updated by the cost of living level index (endogenously solved).

\section{Data sources and calibration methodology}

\subsection{Construction of the regional social accounting data base}

Input-Output $(\mathrm{I} / \mathrm{O})$ data at the regional level are not present in Turkey. The most recent I/O data is tabulated in 2002 by TurkStat. Given the lack of official regional data, we strive to differentiate regional economic activities based on the standard tools of CGE applications. We first update the 2002 I-O table as officially published by TurkStat to 2010 using the national income data on macro-aggregates. Then using the RAS's on sectorial shares, we obtained sectorial components of final demand. Labor remunerations are obtained from ILO and TurkStat Household Labor Force Surveys (HLFS) data.

The aggregated I/O table for 2010 is displayed below.

In reaching the regional SAM (which is available upon request), we decomposed the national macro-aggregates via the shares of gross regional value added (RGVA). Based on our differentiation of the level-2 NACE-1 data, we distinguish 7 regions as "High-
Income" and 19 regions are classified under "Low Income". Data reveal that the Low Income region hosts about $60 \%$ of the total population of 73.7 million persons, and produces about $32 \%$ aggregate value added while the remaining $68 \%$ is originated in the High Income region. For further specifics of the regional macrodata, see Table below.

The SAM tabulates the micro-level I/O data along with the aggregate macro data on public sector balances and resolution of the saving-investment equilibrium. The latter discloses a current account deficit (foreign savings) of TL72.5 billion (roughly $6.5 \%$ to the GDP). The two regions identified, High versus Low Income Turkey yield the production activities; while components of aggregate national demand are revealed by way of imperfect substitution in demand, and are calibrated through standard methods of the Armingtonian composite system.

This procedure is definitely a poor alternative to a more direct approach based on regionally differentiated production structures. This, however, would necessitate regional input-output data along with regional material balances. In the absence of official and/or independent data at the regional level, we had to resort to the Armingtonian imperfect substitutability framework based on cost optimization.

Note that the specification here is designed only to capture the regionally differentiated component of (investment) subsidization, and should not be regarded as a detailed structural characterization of the dualistic (fragmented) patterns of production attributable to the Turkish economy, an issue which is clearly beyond the scope of this paper. 
Table 7

Environmental results.

\begin{tabular}{|c|c|c|c|c|c|c|c|c|c|c|c|c|}
\hline & \multicolumn{4}{|c|}{ Base path } & \multicolumn{4}{|c|}{ Scenario 1: Eliminate production subsidies on coal } & \multicolumn{4}{|c|}{$\begin{array}{l}\text { Scenario 2: Eliminate both production and investment subsidies on } \\
\text { coal }\end{array}$} \\
\hline & 2015 & 2020 & 2025 & 2030 & 2015 & 2020 & 2025 & 2030 & 2015 & 2020 & 2025 & 2030 \\
\hline CO2 total, Mill tons & 406.2 & 493.3 & 584.3 & 682.3 & 392.9 & 477.6 & 566.3 & 662.2 & 377.7 & 459.4 & 545.4 & 638.5 \\
\hline Total CO2 (Eq), Mill tons, Mill tons & 506.0 & 604.0 & 708.7 & 821.9 & 492.0 & 587.8 & 690.4 & 801.6 & 476.0 & 569.0 & 669.0 & 777.4 \\
\hline $\begin{array}{l}\text { High income, } \mathrm{CO} 2 \text { emissions from coal burning } \\
\text { for energy }\end{array}$ & 47.8 & 55.2 & 61.4 & 67.4 & 38.2 & 44.1 & 49.1 & 54.0 & 27.2 & 31.5 & 35.1 & 38.6 \\
\hline $\begin{array}{l}\text { Low income, } \mathrm{CO} 2 \text { emissions from coal burning } \\
\text { for energy }\end{array}$ & 12.6 & 15.5 & 18.4 & 20.9 & 10.0 & 12.4 & 14.8 & 16.7 & 7.2 & 8.9 & 10.5 & 12.0 \\
\hline High income, $\mathrm{CO} 2$ energy related & 218.6 & 258.5 & 293.8 & 328.7 & 209.9 & 248.4 & 282.5 & 316.3 & 200.2 & 237.1 & 269.8 & 302.3 \\
\hline Low income, $\mathrm{CO} 2$ energy related & 61.3 & 78.0 & 94.9 & 109.4 & 59.0 & 75.2 & 91.5 & 105.6 & 56.5 & 72.0 & 87.8 & 101.2 \\
\hline High income, $\mathrm{CO} 2$ industrial processes & 54.0 & 68.7 & 87.8 & 114.4 & 53.8 & 68.4 & 87.5 & 114.0 & 53.5 & 68.0 & 87.0 & 113.3 \\
\hline Low income, $\mathrm{CO} 2$ industrial processes & 12.5 & 15.9 & 20.3 & 24.8 & 12.5 & 15.9 & 20.3 & 24.7 & 12.4 & 15.8 & 20.1 & 24.5 \\
\hline High income, $\mathrm{CO} 2$ eq: Agriculture & 24.8 & 28.8 & 32.6 & 38.9 & 24.8 & 28.8 & 32.6 & 38.9 & 24.8 & 28.7 & 32.5 & 38.8 \\
\hline Low income, $\mathrm{CO} 2$ eq: Agriculture & 24.6 & 31.8 & 38.7 & 43.9 & 24.6 & 31.8 & 38.7 & 43.9 & 24.6 & 31.8 & 38.6 & 43.8 \\
\hline CO2 households & 59.8 & 72.2 & 87.4 & 105.1 & 57.8 & 69.7 & 84.5 & 101.7 & 55.1 & 66.5 & 80.7 & 97.1 \\
\hline Total $\mathrm{CO} 2$ energy related & 339.7 & 408.7 & 476.1 & 543.2 & 326.7 & 393.3 & 458.6 & 523.6 & 311.8 & 375.6 & 438.3 & 500.7 \\
\hline Total CO2/GDP (kg/\$GDP) & 0.535 & 0.535 & 0.528 & 0.518 & 0.518 & 0.518 & 0.512 & 0.503 & 0.499 & 0.500 & 0.495 & 0.487 \\
\hline CO2 from Energy/GDP(kg/\$GDP) & 0.447 & 0.443 & 0.430 & 0.412 & 0.431 & 0.427 & 0.415 & 0.398 & 0.412 & 0.409 & 0.398 & 0.382 \\
\hline Intermediate demand coal in low income & 2.302 & 2.707 & 3.194 & 3.705 & 1.839 & 2.164 & 2.556 & 2.968 & 1.311 & 1.543 & 1.826 & 2.125 \\
\hline Intermediate demand coal in high income & 4.239 & 4.941 & 5.761 & 6.835 & 3.389 & 3.951 & 4.612 & 5.478 & 2.416 & 2.818 & 3.296 & 3.922 \\
\hline Intermediate demand Petr\&Gas in low income & 12.961 & 16.086 & 19.871 & 23.790 & 13.043 & 16.181 & 19.979 & 23.914 & 13.148 & 16.293 & 20.101 & 24.046 \\
\hline Intermediate demand Petr\&Gas in high income & 23.266 & 28.245 & 34.314 & 41.958 & 23.416 & 28.416 & 34.508 & 42.183 & 23.613 & 28.625 & 34.734 & 42.434 \\
\hline Intermediate demand Ref Petr in low income & 62.632 & 78.443 & 97.802 & 117.526 & 62.527 & 78.309 & 97.628 & 117.315 & 62.361 & 78.065 & 97.291 & 116.880 \\
\hline Intermediate demand Ref Petr in high income & 103.463 & 128.010 & 157.713 & 195.276 & 103.317 & 127.823 & 157.476 & 194.982 & 103.087 & 127.475 & 156.996 & 194.343 \\
\hline
\end{tabular}


Table 8

Real Output (Bill TL, 2010 fixed prices)

\begin{tabular}{|c|c|c|c|c|c|c|c|c|c|c|c|c|c|}
\hline & \multirow[t]{2}{*}{ Sector } & \multicolumn{4}{|l|}{ Base path } & \multicolumn{4}{|c|}{ Scenario 1: eliminate production subsidies on coal } & \multicolumn{4}{|c|}{ Scenario 2: eliminate both production and investment subsidies on coal } \\
\hline & & 2015 & 2020 & 2025 & 2030 & 2015 & 2020 & 2025 & 2030 & 2015 & 2020 & 2025 & 2030 \\
\hline \multicolumn{14}{|c|}{ Real output by sectors, low income region (Bill TL, 2010 fixed prices) } \\
\hline AG & Agriculture & 182.861 & 236.169 & 286.969 & 325.894 & 182.951 & 236.249 & 236.249 & 325.892 & 182.898 & 236.045 & 286.598 & 325.322 \\
\hline CO & Coal & 2.517 & 2.983 & 3.548 & 4.057 & 1.796 & 2.129 & 2.129 & 2.894 & 1.162 & 1.376 & 1.635 & 1.867 \\
\hline PG & Crude Oil and Natural Gas & 1.482 & 2.125 & 2.811 & 3.310 & 1.495 & 2.142 & 2.142 & 3.334 & 1.511 & 2.162 & 2.855 & 3.359 \\
\hline PE & Refined Petroleum & 54.129 & 71.191 & 91.789 & 111.123 & 54.081 & 71.122 & 71.122 & 110.999 & 53.985 & 70.955 & 91.437 & 110.661 \\
\hline CE & Cement & 15.758 & 19.452 & 23.772 & 27.799 & 15.686 & 19.362 & 19.362 & 27.673 & 15.580 & 19.223 & 23.485 & 27.464 \\
\hline IS & Iron and Steel & 24.705 & 33.105 & 45.011 & 57.756 & 24.616 & 32.981 & 32.981 & 57.536 & 24.495 & 32.803 & 44.581 & 57.195 \\
\hline MW & Machinery and White Goods & 29.864 & 37.092 & 45.712 & 53.859 & 29.818 & 37.033 & 37.033 & 53.766 & 29.744 & 36.924 & 45.485 & 53.577 \\
\hline ET & Electronics & 17.280 & 23.245 & 30.995 & 38.017 & 17.260 & 23.217 & 23.217 & 37.967 & 17.226 & 23.159 & 30.866 & 37.847 \\
\hline AU & Auto Industry & 18.021 & 25.688 & 37.714 & 49.599 & 18.031 & 25.705 & 25.705 & 49.659 & 18.032 & 25.701 & 37.746 & 49.664 \\
\hline EL & Electricity Production & 31.285 & 41.457 & 53.823 & 65.958 & 31.345 & 41.526 & 41.526 & 66.040 & 31.420 & 41.594 & 53.949 & 66.073 \\
\hline CN & Construction & 55.667 & 70.042 & 84.552 & 97.496 & 55.670 & 70.037 & 70.037 & 97.468 & 55.609 & 69.927 & 84.362 & 97.244 \\
\hline $\mathrm{OE}$ & Other Economy & 622.220 & 744.168 & 893.265 & 1029.015 & 621.321 & 743.034 & 743.034 & 1027.328 & 619.628 & 740.669 & 888.688 & 1023.454 \\
\hline \multicolumn{14}{|c|}{ Real output by sectors, high income region (Bill TL, 2010 fixed prices) } \\
\hline AG & Agriculture & 55.100 & 63.839 & 72.344 & 86.319 & 55.077 & 63.809 & 72.306 & 86.268 & 55.036 & 63.733 & 72.199 & 86.112 \\
\hline co & Coal & 4.994 & 5.798 & 6.682 & 7.879 & 3.568 & 4.142 & 4.773 & 5.626 & 1.852 & 2.149 & 2.474 & 2.914 \\
\hline PG & Crude Oil and Natural Gas & 2.199 & 2.693 & 3.096 & 3.627 & 2.217 & 2.714 & 3.119 & 3.652 & 2.241 & 2.741 & 3.147 & 3.683 \\
\hline PE & Refined Petroleum & 95.268 & 120.626 & 151.567 & 190.783 & 95.183 & 120.510 & 151.417 & 190.589 & 95.043 & 120.273 & 151.069 & 190.100 \\
\hline CE & Cement & 30.796 & 37.901 & 45.943 & 56.575 & 30.678 & 37.754 & 45.765 & 56.354 & 30.506 & 37.525 & 45.477 & 55.984 \\
\hline IS & Iron and Steel & 48.444 & 65.054 & 89.841 & 125.697 & 48.294 & 64.848 & 89.553 & 125.283 & 48.103 & 64.560 & 89.128 & 124.652 \\
\hline MW & Machinery and White Goods & 58.242 & 72.754 & 89.156 & 111.180 & 58.204 & 72.703 & 89.088 & 111.092 & 58.142 & 72.592 & 88.921 & 110.853 \\
\hline ET & Electronics & 32.357 & 41.541 & 54.504 & 72.607 & 32.329 & 41.504 & 54.455 & 72.542 & 32.288 & 41.432 & 54.347 & 72.382 \\
\hline AU & Auto Industry & 34.203 & 44.370 & 63.590 & 95.340 & 34.225 & 44.401 & 63.656 & 95.484 & 34.245 & 44.414 & 63.690 & 95.587 \\
\hline EL & Electricity Production & 53.754 & 67.655 & 84.709 & 106.287 & 53.849 & 67.762 & 84.826 & 106.419 & 53.987 & 67.889 & 84.938 & 106.511 \\
\hline CN & Construction & 96.065 & 112.904 & 129.886 & 153.346 & 96.055 & 112.884 & 129.851 & 153.295 & 95.964 & 112.724 & 129.618 & 152.969 \\
\hline OE & Other Economy & 1253.900 & 1506.745 & 1781.172 & $2,135.624$ & 1253.532 & 1506.144 & 1780.299 & $2,134.413$ & 1252.283 & 1503.795 & 1776.800 & $2,129.466$ \\
\hline
\end{tabular}




\begin{tabular}{|c|c|c|c|c|c|c|c|c|c|c|c|c|c|}
\hline & \multirow[t]{2}{*}{ Sector } & \multicolumn{4}{|c|}{ Base path } & \multicolumn{4}{|c|}{$\begin{array}{l}\text { Scenario 1: eliminate production subsidies } \\
\text { on coal }\end{array}$} & \multicolumn{4}{|c|}{$\begin{array}{l}\text { Scenario 2: eliminate both production and in- } \\
\text { vestment subsidies on coal }\end{array}$} \\
\hline & & 2015 & 2020 & 2025 & 2030 & 2015 & 2020 & 2025 & 2030 & 2015 & 2020 & 2025 & 2030 \\
\hline \multicolumn{14}{|c|}{ Capital stocks by sectors, low income region (Bill TL, 2010 fixed prices) } \\
\hline AG & Agriculture & 97.577 & 136.008 & 172.299 & 196.418 & 97.697 & 136.144 & 172.408 & 196.516 & 97.727 & 136.077 & 172.197 & 196.185 \\
\hline CO & Coal & 0.183 & 0.246 & 0.308 & 0.350 & 0.131 & 0.176 & 0.220 & 0.250 & 0.064 & 0.086 & 0.108 & 0.122 \\
\hline PG & $\begin{array}{l}\text { Crude oil and } \\
\text { Natural Gas }\end{array}$ & 0.910 & 1.366 & 1.819 & 2.106 & 0.919 & 1.379 & 1.834 & 2.123 & 0.930 & 1.393 & 1.851 & 2.140 \\
\hline PE & Refined Petroleum & 9.085 & 13.061 & 17.142 & 20.001 & 9.094 & 13.070 & 17.149 & 20.008 & 9.096 & 13.062 & 17.126 & 19.974 \\
\hline CE & Cement & 0.898 & 1.245 & 1.579 & 1.803 & 0.897 & 1.244 & 1.577 & 1.801 & 0.895 & 1.240 & 1.572 & 1.794 \\
\hline IS & Iron and Steel & 1.072 & 1.597 & 2.220 & 2.737 & 1.071 & 1.595 & 2.217 & 2.733 & 1.069 & 1.591 & 2.210 & 2.723 \\
\hline MW & $\begin{array}{l}\text { Machinery and } \\
\text { White Goods }\end{array}$ & 1.841 & 2.558 & 3.250 & 3.711 & 1.843 & 2.559 & 3.250 & 3.712 & 1.842 & 2.557 & 3.245 & 3.705 \\
\hline ET & Electronics & 1.687 & 2.507 & 3.411 & 4.022 & 1.689 & 2.510 & 3.413 & 4.024 & 1.690 & 2.509 & 3.409 & 4.018 \\
\hline AU & Auto Industry & 1.609 & 2.532 & 3.778 & 4.756 & 1.613 & 2.538 & 3.788 & 4.769 & 1.617 & 2.543 & 3.794 & 4.777 \\
\hline $\mathbf{E L}$ & $\begin{array}{l}\text { Electricity } \\
\text { Production }\end{array}$ & 7.637 & 10.855 & 14.165 & 16.651 & 7.701 & 10.940 & 14.268 & 16.768 & 7.782 & 11.043 & 14.386 & 16.896 \\
\hline CN & Construction & 13.739 & 18.948 & 23.431 & 26.300 & 13.765 & 18.979 & 23.460 & 26.330 & 13.776 & 18.979 & 23.444 & 26.301 \\
\hline $\mathbf{O E}$ & Other Economy & 24.060 & 32.701 & 41.276 & 47.042 & 24.077 & 32.717 & 41.283 & 47.046 & 24.067 & 32.677 & 41.205 & 46.940 \\
\hline \multicolumn{14}{|c|}{ Capital stocks by sectors, high income region (Bill TL, 2010 fixed prices) } \\
\hline AG & Agriculture & 25.902 & 29.004 & 30.824 & 34.733 & 25.898 & 28.996 & 30.815 & 34.719 & 25.888 & 28.970 & 30.776 & 34.661 \\
\hline CO & Coal & 2.279 & 2.597 & 2.787 & 3.086 & 1.632 & 1.859 & 1.995 & 2.208 & 0.743 & 0.846 & 0.907 & 1.003 \\
\hline PG & $\begin{array}{l}\text { Crude Oil and } \\
\text { Natural Gas }\end{array}$ & 1.565 & 1.852 & 2.002 & 2.220 & 1.578 & 1.868 & 2.017 & 2.236 & 1.597 & 1.887 & 2.037 & 2.257 \\
\hline PE & Refined Petroleum & 20.583 & 24.672 & 27.750 & 31.868 & 20.585 & 24.673 & 27.749 & 31.865 & 20.585 & 24.658 & 27.723 & 31.825 \\
\hline CE & Cement & 8.298 & 9.810 & 10.792 & 12.248 & 8.290 & 9.798 & 10.779 & 12.232 & 8.275 & 9.776 & 10.750 & 12.194 \\
\hline IS & Iron and Steel & 7.975 & 10.174 & 12.494 & 15.831 & 7.965 & 10.160 & 12.476 & 15.806 & 7.953 & 10.139 & 12.446 & 15.762 \\
\hline MW & $\begin{array}{l}\text { Machinery and } \\
\text { White Goods }\end{array}$ & 16.256 & 19.377 & 21.384 & 24.398 & 16.263 & 19.383 & 21.389 & 24.403 & 16.271 & 19.382 & 21.380 & 24.384 \\
\hline ET & Electronics & 5.402 & 6.615 & 7.741 & 9.364 & 5.404 & 6.617 & 7.744 & 9.367 & 5.407 & 6.618 & 7.742 & 9.362 \\
\hline AU & Auto Industry & 3.950 & 4.906 & 6.244 & 8.458 & 3.957 & 4.915 & 6.257 & 8.480 & 3.966 & 4.924 & 6.270 & 8.502 \\
\hline $\mathbf{E L}$ & $\begin{array}{l}\text { Electricity } \\
\text { Production }\end{array}$ & 14.526 & 17.187 & 19.196 & 21.929 & 14.635 & 17.309 & 19.326 & 22.071 & 14.785 & 17.471 & 19.491 & 22.246 \\
\hline CN & Construction & 30.662 & 34.800 & 36.527 & 39.885 & 30.690 & 34.828 & 36.553 & 39.910 & 30.705 & 34.826 & 36.536 & 39.875 \\
\hline $\mathbf{O E}$ & Other Economy & 486.945 & 566.930 & 618.037 & 692.147 & 487.213 & 567.170 & 618.237 & 692.300 & 487.317 & 566.939 & 617.716 & 691.437 \\
\hline
\end{tabular}

\subsection{Parametrization of gaseous pollutants}

A total of 411.74 million tons of $\mathrm{CO}$ (eq) was reportedly released in Turkey in 2010. TurkStat data distinguish this sum into four sources: energy combustion (284.8 mtons), industrial processes (60.0 mtons), agricultural processes (39.8 mtons), and waste (27.2 mtons). At a different level of aggregation, 326.1 mtons of this sum is due to emissions of $\mathrm{CO} 2,60.44$ mtons is due to emissions of $\mathrm{CH} 4 ; 19.48$ mtons to $\mathrm{N}_{2} \mathrm{O}$, and 5.72 mtons to F-gasses.

In order to direct these data into sectorial sources of origin, we make use of the TurkStat data as reported to the UNFCCC inventory system. The original data on greenhouse gas source and sink categories are used whenever it was possible to make a direct connection between the sectors recognized in the official data and the sectors distinguished in the model: agriculture, refined petroleum, cement, iron and steel, and electricity. We have allocated the remaining unaccounted $\mathrm{CO} 2$ emissions by the share of sectorial intermediate input demand to the aggregate. This exercise yields the following summarization of $\mathrm{CO} 2(e q)$ emissions across production sectors and other activities.

Using data in the above table we first calculate total sectorial emissions, $\mathrm{CO}_{i}^{T O T}$. This sum is then decomposed into three main sources of origin, emissions from combustion of primary energy (EE) and of secondary energy (SE), and from industrial processes (IND). This is done with the aid of Table 1 above. Let $\pi_{S, i}(s \in E E, S E, I N D)$ be a typical element of Table 1 , then:

$\mathrm{CO} 2_{S, i}=\pi_{S, i} \cdot \mathrm{CO} 2_{i}^{\mathrm{TOT}}$

The coefficient $z_{R P, i}$ is then calibrated by (Tables 2 and 3)
$z_{R P, i}=\frac{C O 2_{R P, i}^{S E}}{I N_{R P, i}}$

For distinguishing this aggregate into the regional activities, regional shares of sectorial output had been used. Ideally the source of $\mathrm{CO} 2$ (eq) emissions ought to be used for regions. However, in the absence of precise data across regional measurements, we had to abstain from making ad hoc specifications. For the EE sources of $C O 2(e q)$ emissions across sectors (for $j \in C O$ and $P G$ ) we follow a similar procedure and find $\mathrm{CO}_{j, i}^{E E}$ from data displayed in Table 4 by applying the $\varepsilon_{j, i}$ for $j \in C O$ and $P G$.

\subsection{Calibration of the labor markets}

Two types of labor are distinguished in the model: formal (LF) and informal/vulnerable (LI). The characterization is based on the ILO's definition of vulnerable employment as: informal (unregistered employment that is under any social security coverage) + self-employed + unpaid family labor. Based on these criteria, total employment of 22,594 thousand workers is distributed across regions and sectors using the HLFS data of TurkStat. See Table 5 for parametrization of the labor markets.

In setting the formal labor share in national income, the $\mathrm{I} / \mathrm{O}$ Wage and Salary data is used. Using this point data, we then used the formal/vulnerable employment shares from the HLFS data to reach aggregate wage income data of the informal/vulnerable labor. Finally, by using the sectorial income shares of the I/O table sectorial/regional wage remunerations across labor types are obtained. Full data is summarized in Table 5 above. 


\begin{tabular}{|c|c|c|c|c|c|c|c|c|c|c|c|c|c|}
\hline & \multirow[t]{2}{*}{ Sector } & \multicolumn{4}{|c|}{ Base path } & \multicolumn{4}{|c|}{$\begin{array}{l}\text { Scenario 1: eliminate production subsidies } \\
\text { on coal }\end{array}$} & \multicolumn{4}{|c|}{$\begin{array}{l}\text { Scenario 2: eliminate both production and invest- } \\
\text { ment subsidies on coal }\end{array}$} \\
\hline & & 2015 & 2020 & 2025 & 2030 & 2015 & 2020 & 2025 & 2030 & 2015 & 2020 & 2025 & 2030 \\
\hline \multicolumn{14}{|c|}{ Exports by sectors, low income region (Bill TL, 2010 fixed prices) } \\
\hline AG & Agriculture & 10.465 & 14.968 & 18.302 & 19.294 & 10.503 & 15.017 & 18.354 & 19.347 & 10.541 & 15.060 & 18.393 & 19.381 \\
\hline CO & Coal & 0.002 & 0.003 & 0.003 & 0.004 & 0.001 & 0.001 & 0.002 & 0.002 & 0.000 & 0.001 & 0.001 & 0.001 \\
\hline PG & $\begin{array}{l}\text { Crude Oil and } \\
\text { Natural Gas }\end{array}$ & 0.010 & 0.017 & 0.024 & 0.028 & 0.010 & 0.017 & 0.024 & 0.028 & 0.010 & 0.017 & 0.025 & 0.028 \\
\hline PE & Refined Petroleum & 7.011 & 9.955 & 13.549 & 16.518 & 7.011 & 9.954 & 13.545 & 16.513 & 7.007 & 9.942 & 13.521 & 16.478 \\
\hline CE & Cement & 2.906 & 3.669 & 4.549 & 5.220 & 2.883 & 3.640 & 4.514 & 5.181 & 2.851 & 3.599 & 4.462 & 5.122 \\
\hline IS & Iron and Steel & 7.526 & 10.526 & 14.962 & 19.465 & 7.491 & 10.476 & 14.890 & 19.372 & 7.445 & 10.407 & 14.788 & 19.235 \\
\hline MW & $\begin{array}{l}\text { Machinery and } \\
\text { White Goods }\end{array}$ & 6.157 & 7.885 & 10.001 & 11.733 & 6.149 & 7.874 & 9.986 & 11.715 & 6.136 & 7.854 & 9.957 & 11.678 \\
\hline ET & Electronics & 5.989 & 8.517 & 11.935 & 14.814 & 5.983 & 8.508 & 11.921 & 14.796 & 5.973 & 8.488 & 11.889 & 14.752 \\
\hline AU & Auto Industry & 8.578 & 12.942 & 20.116 & 27.015 & 8.588 & 12.958 & 20.145 & 27.061 & 8.595 & 12.965 & 20.158 & 27.084 \\
\hline EL & $\begin{array}{l}\text { Electricity } \\
\text { Production }\end{array}$ & 0.047 & 0.070 & 0.098 & 0.123 & 0.047 & 0.070 & 0.098 & 0.122 & 0.046 & 0.069 & 0.097 & 0.121 \\
\hline $\mathrm{CN}$ & Construction & 2.447 & 3.305 & 4.159 & 4.734 & 2.449 & 3.308 & 4.161 & 4.737 & 2.450 & 3.307 & 4.158 & 4.732 \\
\hline OE & Other Economy & 55.732 & 66.569 & 79.041 & 87.020 & 55.666 & 66.485 & 78.936 & 86.902 & 55.541 & 66.309 & 78.702 & 86.625 \\
\hline \multicolumn{14}{|c|}{ Exports by sectors, high income region (Bill TL, 2010 fixed prices) } \\
\hline AG & Agriculture & 2.656 & 3.101 & 3.320 & 3.832 & 2.661 & 3.107 & 3.326 & 3.838 & 2.669 & 3.114 & 3.333 & 3.845 \\
\hline CO & Coal & 0.005 & 0.006 & 0.006 & 0.007 & 0.002 & 0.003 & 0.003 & 0.004 & 0.001 & 0.001 & 0.001 & 0.001 \\
\hline PG & $\begin{array}{l}\text { Crude Oil and } \\
\text { Natural Gas }\end{array}$ & 0.012 & 0.015 & 0.016 & 0.018 & 0.012 & 0.015 & 0.016 & 0.019 & 0.013 & 0.015 & 0.017 & 0.019 \\
\hline PE & Refined Petroleum & 12.049 & 16.022 & 20.877 & 27.237 & 12.049 & 16.021 & 20.875 & 27.233 & 12.049 & 16.011 & 20.855 & 27.199 \\
\hline CE & Cement & 5.970 & 7.494 & 9.164 & 11.462 & 5.931 & 7.446 & 9.106 & 11.390 & 5.877 & 7.377 & 9.020 & 11.280 \\
\hline IS & Iron and Steel & 15.356 & 21.507 & 31.212 & 45.933 & 15.298 & 21.424 & 31.092 & 45.752 & 15.227 & 21.315 & 30.924 & 45.492 \\
\hline MW & $\begin{array}{l}\text { Machinery and } \\
\text { White Goods }\end{array}$ & 12.577 & 16.240 & 20.391 & 26.206 & 12.578 & 16.241 & 20.391 & 26.204 & 12.581 & 16.236 & 20.378 & 26.178 \\
\hline ET & Electronics & 11.379 & 15.113 & 20.710 & 28.868 & 11.372 & 15.104 & 20.697 & 28.851 & 11.364 & 15.086 & 20.668 & 28.803 \\
\hline AU & Auto Industry & 16.527 & 22.011 & 33.240 & 52.662 & 16.547 & 22.039 & 33.293 & 52.773 & 16.572 & 22.065 & 33.343 & 52.880 \\
\hline EL & $\begin{array}{l}\text { Electricity } \\
\text { Production }\end{array}$ & 0.077 & 0.103 & 0.134 & 0.176 & 0.076 & 0.102 & 0.134 & 0.174 & 0.076 & 0.101 & 0.132 & 0.173 \\
\hline $\mathbf{C N}$ & Construction & 4.008 & 4.755 & 5.460 & 6.501 & 4.011 & 4.758 & 5.463 & 6.504 & 4.013 & 4.758 & 5.461 & 6.499 \\
\hline $\mathbf{O E}$ & Other Economy & 121.844 & 146.795 & 169.551 & 201.030 & 121.955 & 146.911 & 169.671 & 201.150 & 122.064 & 146.953 & 169.648 & 201.040 \\
\hline
\end{tabular}

\section{Results and discussion of the policy analysis}

\subsection{The "business-as-usual" base path}

Following the general CGE tradition, we start by integrating a "business-as-usual" base path into our analysis. This will be used as a reference path to assess the macroeconomic and environmental performance of our policy scenarios.

Over this path we first introduce the projections of the exogenously specified flows and parameters. "Population" growth rates for the two labor types across regions are adapted from the UN projections and TurkStat data, and are set at $2 \%$ per annum for low income region; and $0.8 \%$ for the high income region. The migration elasticity parameter in Eq. (16) is taken as 0.05 for both labor types. Capital stocks are updated by new (fixed) investments net of depreciation. Both the depreciation rate and sectorial/regional total factor productivity (TFP) growth rates (growth rate of A in Eq. (3) above) are adjusted to obtain the projected growth of the domestic economy over $2015-2030$, at the rate of $4 \%$ per annum. Detailed official growth projections are given for Turkey, albeit on a very rough analytical backing, and for a short duration. The Medium Term Programme, for instance, follows a 5\% target in its macroeconomic projections over 2014-2017. In contrast, OECD (2014) and IMF's World Economic Outlook (2015, April) projections suggest that the Turkish growth rates will likely be on the order of 3.5-4.0\% over the next decade. Stockholm Environment Institute's Climate Equity Reference Calculator (C-EQR) also uses a $3.6 \%$ rate of growth per annum in its projections for the Turkish economy towards 2030. Given these international evidence and data, we adopted the average annual growth target of $4 \%$ as our base path rate over the 2015-2030 horizon. This assumption brings the aggregate real GDP to 2371 billion TRY in 2030 (in fixed 2010 prices), with an aggregate gross production of 3145 billion TRY in the high income region, and of 1864 billion TRY in the low income region (see Table 6).

Exogenous foreign flows are set at their historical ratios to GDP, and were gradually reduced to yield a current account deficit of $3.1 \%$ by 2030 . Currently this deficit stands at around $5 \%$ and is regarded as an important source of fragility for the Turkish economy, raising concerns over its sustainability. In the labor markets, formal wage rates were maintained at their real levels by continuously updating with the "price level" as solved endogenously by the model. Finally, government's fiscal parameters are left intact at their current (historically realized) levels.

The model is solved sequentially up to 2030 with each "solution" referring to a calendar year. We document a summary of macro and environment indicators of this base path in the first part of Table 6 . With an average annual rate of growth of $4 \%$ over 2015-2030, Turkish aggregate CO2 emissions reach to 682 million tons (to 821.9 million tons of $\mathrm{CO} 2(\mathrm{eq})$ gaseous emissions in total). This is reported to stand at 459 million tons of CO2(eq) in 2013 by the TurkStat (Table 7).

In terms of efficiency, we observe that total $\mathrm{CO} 2$ emissions per unit of GDP initially stand at $0.535 \mathrm{~kg}$ per US\$ GDP until 2020, and recede to $0.518 \mathrm{~kg} /$ \$GDP by the end of 2030 . This fall is due to the gains in efficiency implicitly attained by applications of the (exogenous) gains in sectorial/regional TFPs.

It has to be noted from the outset that this procedure by no means gives a projection of the domestic economy to be read from a crystal ball; but rather, should be regarded as a historically trended future path against which alternative policy environments can be contrasted. In fact, at the time of writing Turkey had 


\begin{tabular}{|c|c|c|c|c|c|c|c|c|c|c|c|c|c|}
\hline & & \multicolumn{4}{|c|}{ Base path } & \multicolumn{4}{|c|}{$\begin{array}{l}\text { Scenario 1: eliminate production subsidies } \\
\text { on coal }\end{array}$} & \multicolumn{4}{|c|}{$\begin{array}{l}\text { Scenario 2: eliminate both production and invest- } \\
\text { ment subsidies on coal }\end{array}$} \\
\hline & & 2015 & 2020 & 2025 & 2030 & 2015 & 2020 & 2025 & 2030 & 2015 & 2020 & 2025 & 2030 \\
\hline \multicolumn{14}{|c|}{ Aggregate energy demand by sectors, low income region (Bill TL, 2010 fixed prices) } \\
\hline AG & Agriculture & 0.834 & 1.063 & 1.322 & 1.580 & 0.825 & 1.052 & 1.308 & 1.564 & 0.812 & 1.036 & 1.288 & 1.540 \\
\hline CO & Coal & 0.138 & 0.169 & 0.206 & 0.245 & 0.096 & 0.117 & 0.143 & 0.170 & 0.061 & 0.074 & 0.091 & 0.108 \\
\hline PG & $\begin{array}{l}\text { Crude Oil and Nat- } \\
\text { ural Gas }\end{array}$ & 0.071 & 0.097 & 0.126 & 0.152 & 0.071 & 0.097 & 0.126 & 0.152 & 0.072 & 0.098 & 0.126 & 0.153 \\
\hline PE & Refined Petroleum & 7.859 & 10.017 & 12.602 & 15.203 & 7.844 & 9.996 & 12.576 & 15.171 & 7.819 & 9.959 & 12.525 & 15.105 \\
\hline CE & Cement & 0.888 & 1.109 & 1.364 & 1.621 & 0.858 & 1.072 & 1.321 & 1.570 & 0.819 & 1.024 & 1.262 & 1.502 \\
\hline IS & Iron and Steel & 1.424 & 1.937 & 2.641 & 3.411 & 1.406 & 1.913 & 2.609 & 3.370 & 1.383 & 1.881 & 2.565 & 3.314 \\
\hline MW & $\begin{array}{l}\text { Machinery and } \\
\text { White Goods }\end{array}$ & 0.493 & 0.627 & 0.782 & 0.937 & 0.489 & 0.622 & 0.777 & 0.931 & 0.484 & 0.616 & 0.769 & 0.921 \\
\hline ET & Electronics & 0.559 & 0.755 & 1.003 & 1.237 & 0.554 & 0.749 & 0.995 & 1.227 & 0.548 & 0.740 & 0.983 & 1.212 \\
\hline AU & Auto Industry & 0.164 & 0.236 & 0.345 & 0.455 & 0.163 & 0.235 & 0.344 & 0.454 & 0.162 & 0.233 & 0.342 & 0.451 \\
\hline EL & $\begin{array}{l}\text { Electricity } \\
\text { Production }\end{array}$ & 17.799 & 22.945 & 29.204 & 35.869 & 17.765 & 22.899 & 29.141 & 35.790 & 17.721 & 22.829 & 29.038 & 35.651 \\
\hline $\mathrm{CN}$ & Construction & 0.164 & 0.206 & 0.250 & 0.294 & 0.162 & 0.203 & 0.247 & 0.290 & 0.158 & 0.199 & 0.242 & 0.285 \\
\hline OE & Other Economy & 9.847 & 12.145 & 14.953 & 17.806 & 9.674 & 11.937 & 14.704 & 17.515 & 9.441 & 11.653 & 14.359 & 17.107 \\
\hline \multicolumn{14}{|c|}{ Aggregate energy demand by sectors, high income region (Bill TL, 2010 fixed prices) } \\
\hline AG & Agriculture & 0.274 & 0.328 & 0.393 & 0.483 & 0.271 & 0.325 & 0.389 & 0.478 & 0.266 & 0.319 & 0.383 & 0.471 \\
\hline CO & Coal & 0.263 & 0.318 & 0.382 & 0.459 & 0.182 & 0.221 & 0.265 & 0.319 & 0.103 & 0.125 & 0.151 & 0.181 \\
\hline PG & $\begin{array}{l}\text { Crude Oil and Nat- } \\
\text { ural Gas }\end{array}$ & 0.116 & 0.146 & 0.177 & 0.214 & 0.117 & 0.147 & 0.178 & 0.214 & 0.118 & 0.148 & 0.178 & 0.215 \\
\hline PE & Refined Petroleum & 13.998 & 17.415 & 21.542 & 26.634 & 13.970 & 17.379 & 21.498 & 26.578 & 13.928 & 17.319 & 21.416 & 26.471 \\
\hline CE & Cement & 1.693 & 2.110 & 2.582 & 3.176 & 1.636 & 2.042 & 2.501 & 3.078 & 1.563 & 1.951 & 2.393 & 2.946 \\
\hline IS & Iron and Steel & 2.738 & 3.733 & 5.156 & 7.129 & 2.705 & 3.689 & 5.096 & 7.047 & 2.661 & 3.630 & 5.014 & 6.934 \\
\hline MW & $\begin{array}{l}\text { Machinery and } \\
\text { White Goods }\end{array}$ & 0.939 & 1.200 & 1.492 & 1.860 & 0.933 & 1.192 & 1.483 & 1.849 & 0.925 & 1.181 & 1.469 & 1.832 \\
\hline ET & Electronics & 1.039 & 1.354 & 1.776 & 2.339 & 1.031 & 1.343 & 1.762 & 2.321 & 1.019 & 1.328 & 1.742 & 2.295 \\
\hline AU & Auto Industry & 0.309 & 0.410 & 0.587 & 0.868 & 0.308 & 0.409 & 0.585 & 0.866 & 0.306 & 0.406 & 0.582 & 0.862 \\
\hline EL & $\begin{array}{l}\text { Electricity } \\
\text { Production }\end{array}$ & 31.434 & 39.488 & 49.353 & 61.339 & 31.373 & 39.408 & 49.248 & 61.204 & 31.298 & 39.292 & 49.083 & 60.978 \\
\hline $\mathrm{CN}$ & Construction & 0.290 & 0.352 & 0.416 & 0.495 & 0.286 & 0.347 & 0.410 & 0.489 & 0.280 & 0.340 & 0.402 & 0.479 \\
\hline OE & Other Economy & 19.051 & 23.562 & 28.748 & 35.026 & 18.730 & 23.175 & 28.287 & 34.475 & 18.298 & 22.645 & 27.649 & 33.702 \\
\hline
\end{tabular}

announced its Intended Nationally Determined Contribution (INDC) programme to the UNFCCC as part of its efforts to report in the COPE 21 meetings in Paris, December 2015. The official INDC traces a business-as-usual, base-path covering 2013 to 2030, and reveals a projected path for gaseous emissions reaching to 1175 million tones of $\mathrm{CO} 2(\mathrm{eq}){ }^{2}$ This projection is significantly higher than our base path specification which puts aggregate $\mathrm{CO} 2(\mathrm{eq})$ emissions to 821.9 mtons by $2030 .^{3}$ This difference could be due to several reasons. One is that the assumed growth rate of GDP could have been significantly higher than our projected average rate of growth of $4 \%$; or at comparable growth rate projections, the officially assumed path might have involved an increase in the carbon intensity per \$GDP. Thirdly, the difference in the projected base paths may also be based on differences in modeling techniques. The official projection, being based mostly on a bottom-up approach, aims at cost minimization given a path of economic activity. The CGE model utilized in this study, in contrast, is based on an up-bottom approach with the level of economic activity being solved endogenously and releasing its environmental impacts as dependent outcomes. ${ }^{4}$ In any event, the official INDC is observed to reveal an acceleration in total emissions by $155 \%$ from 459 mtons in 2013, to the projected 1175 mtons of CO2(eq) in 2030. Considering that over a period of twenty three years from 1990 to 2013 aggregate CO2(eq) emissions had increased by only a

\footnotetext{
${ }^{2}$ Ministry of the Environment and Urban Affairs, retrieved from http://www4 unfccc.int/submissions/INDC/Published\%20Documents/Turkey/1/The_INDC_of_TUR KEY_v.15.19.30.pdf.

${ }^{3}$ We are grateful to an anonymous referee of the Energy Policy for bringing this issue to our attention.

${ }^{4}$ On the difference and discussions of up-bottom versus bottom-up approaches, see Bohringer and Loeschel (2006).
}

total of $110 \%$, suggest that the official INDC projections are not in line with the recent Turkish historical pathway.

\subsection{Investigating alternative policy scenarios}

Given our policy questions we first intervene to the coal market and study implications of eliminating the existing subsidization scheme. To this end we first investigate the macro and environmental implications of eliminating the subsidies on coal production. As discussed in Section 1, the existing scheme of coal subsidization amounts to $730 \mathrm{~m}$ US\$, on the average of $0.1 \%$ as a ratio to the GDP. In the first scenario we reduce this subsidy to zero.

\subsubsection{Eliminate subsidies on coal production}

Elimination of the coal subsidies generates contractionary pressures in coal production. As of 2030 coal production falls by $29 \%$ in both regions. These imply a reduction of $0.17 \%$ in the aggregate real gross domestic product by 2030 , or a total 4 billion TRY in fixed 2010 prices. Gains in total CO2(eq) are on the order of $2.5 \%$ (20.3 million tons) over the base path by 2030 . The bulk of these gains originates from reductions of emissions from coal combustion, 4.2 million tons in low income; 13.4 million tons in the high income region. There is a further reduction of $3.2 \%$ (3.4 million tons) of energy related emissions from the household sector. These numbers imply that $\mathrm{CO} 2$ emissions from energy per \$ of GDP fall to $0.398 \mathrm{~kg}$ under the scenario, from $0.412 \mathrm{~kg}$ of the base path (see Table 6).

Clearly, all these findings are the end-result of the reallocation of resources due to the general equilibrium dynamics across sectors and regions. We find that there is a slight increase in the average unemployment rate by $0.1 \%$, with no change in the high 
Table 12

Support measures of the regional investment incentive scheme.

Source: Ministry of economy (Table and notes retrieved from http://www.ekonomi gov.tr/portal/faces/home/yatirim/yatirimTesvik/yatirimTesvik-Genel_Bilgi)

\begin{tabular}{|c|c|c|c|c|c|c|c|}
\hline \multicolumn{2}{|l|}{ Support measures } & \multicolumn{6}{|c|}{ Regions } \\
\hline & & 1 & 2 & 3 & 4 & 5 & 6 \\
\hline \multirow{2}{*}{\multicolumn{2}{|c|}{$\begin{array}{l}\text { VAT exemption } \\
\text { Customs duty exemption }\end{array}$}} & Yes & Yes & Yes & Yes & Yes & Yes \\
\hline & & Yes & Yes & Yes & Yes & Yes & Yes \\
\hline \multirow[t]{3}{*}{ Tax deduction } & $\begin{array}{l}\text { Tax reduction } \\
\text { rate }(\%)\end{array}$ & 30 & 40 & 50 & 60 & 70 & 90 \\
\hline & $\begin{array}{l}\text { Reduced tax rate } \\
(\%)\end{array}$ & 14 & 12 & 10 & 8 & 6 & 2 \\
\hline & $\begin{array}{l}\text { Rate of contribu- } \\
\text { tion }(\%)\end{array}$ & 10 & 15 & 20 & 25 & 30 & 35 \\
\hline $\begin{array}{l}\text { Social Security Pre- } \\
\text { mium (SSP) }\end{array}$ & $\begin{array}{l}\text { Term of support } \\
\text { (years) }\end{array}$ & - & - & 3 & 5 & 6 & 7 \\
\hline $\begin{array}{l}\text { Support (Em- } \\
\text { ployer's Share) }^{\mathrm{d}}\end{array}$ & $\begin{array}{l}\text { Cap for support } \\
\text { (Certain Portion } \\
\text { of Investment } \\
\text { Amount - \%) }\end{array}$ & - & - & 20 & 25 & 35 & No limit \\
\hline Land allocation $^{\mathrm{e}}$ & & Yes & Yes & Yes & Yes & Yes & Yes \\
\hline \multirow[t]{3}{*}{$\begin{array}{l}\text { Interest rate } \\
\text { support }^{\mathrm{f}}\end{array}$} & $\begin{array}{l}\text { TL denominated } \\
\text { loans (points) }\end{array}$ & - & - & 3 & 4 & 5 & 7 \\
\hline & FX Loans (points) & & & 1 & 1 & 2 & 2 \\
\hline & $\begin{array}{l}\text { Cap for support } \\
\text { (Thousand TL) }\end{array}$ & - & - & 500 & 600 & 700 & 900 \\
\hline \multicolumn{2}{|c|}{$\begin{array}{l}\text { SSP support (Employee's share) } \\
\text { (years) }^{\mathrm{g}}\end{array}$} & - & - & - & - & - & 10 \\
\hline \multicolumn{2}{|c|}{$\begin{array}{l}\text { Income tax withholding support } \\
\quad(\text { years })^{\mathrm{h}}\end{array}$} & - & - & - & - & - & 10 \\
\hline
\end{tabular}

Notes: For investments starting as of January 1, 2015. The new investment incentives system defines certain investment areas including coal mining and coal fired power generation as "priority" areas and grants them with the regional support measures defined for Region 5, regardless of the region of investment. If the fixed investment amount in priority investments is TRY 1 billion or more, tax reduction will be applied by adding 10 points on top of the "rate of contribution to investment" available in Region 5. If priority investments are made in Region 6, the regional incentives available for this particular region shall apply.

a In accordance with the measure, VAT is not paid for imported and/or domestically provided machinery and equipment within the scope of the investment encouragement certificate.

${ }^{\mathrm{b}}$ Customs duty is not paid for the machinery and equipment provided from abroad (imported) within the scope of the investment encouragement certificate.

c Calculation of income or corporate tax with reduced rates until the total value reaches to the amount of contribution to the investment according to envisaged rate of contribution.

${ }^{d}$ The measure stipulates that for the additional employment created by the investment, employer's share of social security premium on portions of labor wages corresponding to amount of legal minimum wage, will be covered by the Ministry.

e Refers to allocation of land to the investments with investment incentive certificates, if any in that province in accordance with the rules and principles determined by the Ministry of Finance.

$\mathrm{f}$ Interest support, is a financial support instrument, provided for the loans with a term of at least one year obtained within the frame of the investment encouragement certificate. The measure stipulates that a certain portion of the interest/profit share regarding the loan equivalent of at most $70 \%$ of the fixed investment amount registered in the certificate will be covered by the Ministry.

$\mathrm{g}$ The measure stipulates that for the additional employment created by the investment, employee's share of social security premium on portions of labor wages corresponding to amount of legal minimum wage, will be covered by the Ministry. The measure is applicable only for the investments to be made in Region 6 within the scope of an investment encouragement certificate.

${ }^{\mathrm{h}}$ The measure stipulates that the income tax regarding the additional employment generated by the investment within the scope of the investment encouragement certificate will not be liable to withholding. The measure is applicable only for the investments to be made in Region 6 within the scope of an investment encouragement certificate.

income region while in the low income region it rises by 0.2 percentage points. Due to the deceleration of the economic activity, there is a fall in aggregate investment and consumption expenditures, yet these effects are found to be comparably small. These observations suggest that owing to substitution effects, domestic production activity helps recovery of the aggregate economy; and in the final analysis, the gains in pollution abatement are relatively noteworthy. More detailed sectorial and regional summary of these results are documented in Tables 8 through 11 .

\subsubsection{Eliminate investment subsidies on coal}

Coal mining is further subsidized under the Regional Investment Incentives Scheme (see Table 12 for a detailed outline of the scheme). Accordingly, investment expenditures on coal mining are supported by the central government to boost coal production across regions. Via reduced income or corporate taxes, the existing scheme subsidizes the cost of investments at a rate of $30 \%$ in the high income region, and by $35 \%$ in the low income region. In this scenario, in addition to eliminating producer subsidies in coal production (Scenario 1) we further eliminate the investment subsidization programme in the coal sector. The results are tabulated under the "scenario 2" part of Tables 6 through 11, and also portrayed in Figs. 2 through 4.

We find the macro-effects of the scenario quite small. GDP loss by 2030 is only $0.5 \%$ suggesting that substitution effects on the reallocation of capital across the remaining sectors dominate. Yet, the abatement on $\mathrm{CO} 2$ emissions continue and in comparison to the base path the combined scenario brings about a 5.4\% reduction in aggregate $\mathrm{CO} 2$ (eq) emissions (in 2030). In the high income region reduction of $\mathrm{CO} 2$ emissions from coal burning reach to $42.7 \%$ and in the low income region it reaches to $42.6 \%$. Total abatement of energy related $\mathrm{CO} 2$ emissions reach to 42.5 million tons (Fig. 3), and the ratio of $\mathrm{CO} 2$ from energy to GDP is reduced further to $0.382 \mathrm{~kg} / \$$ (Fig. 4).

It has to be noted that the model results obtained through the scenario pathways are ultimately limited to adjustments implied within the domestic economy. As discussed above, the current account deficit is an important fragility indicator for Turkish economy and energy imports is responsible for a significant share of this deficit. Therefore, any policy which alters the energy mix in Turkey is expected to have an impact on the resolution of the current account deficit. Yet, the model's closure rule specifies that even though the balance on the current account is endogenous to the model, it nevertheless depends on the inflows of foreign capital (in the form of workers' remittances, profit transfers, portfolio and foreign direct investments, and net debt flows) which are exogenously given as ratios to the GDP over the dynamic pathways. This specification sets the boundaries of adjustment in the current account balance. This is clearly an undesirable feature of our dynamic results; and yet, in the absence of any evidence on how a fiscal policy of elimination of coal subsidies night affect foreign capital inflows we had to abstain from making ad hoc assumptions on the nature of adjustments in the current account.

\section{Conclusion and policy implications}

In this paper we assessed the impact of the current arsenal of energy policy instruments (in particular coal subsidies) on macroindicators and environmental outcomes, specifically $\mathrm{CO} 2$ emissions in Turkey. Consequently, the implications of the removal of coal subsidies are explored. The findings suggest that elimination of production and investment subsidies for coal results in a slight reduction of GDP (by $0.5 \%$ as of 2030 ) but a substantial decrease in $\mathrm{CO} 2$ emissions both in the low and high income regions. Considering that a relatively small coal sector benefits from significant subsidies, the elimination of these motives alone will considerably benefit the environment. 


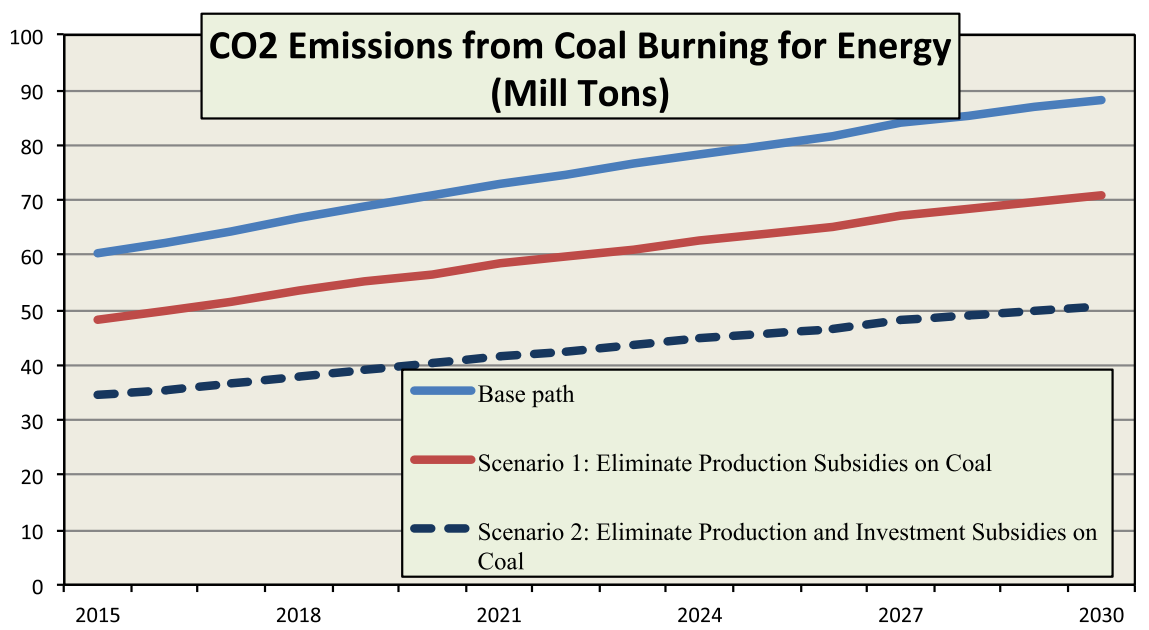

Fig. 2. CO2 emissions from coal burning for energy (mill tons).

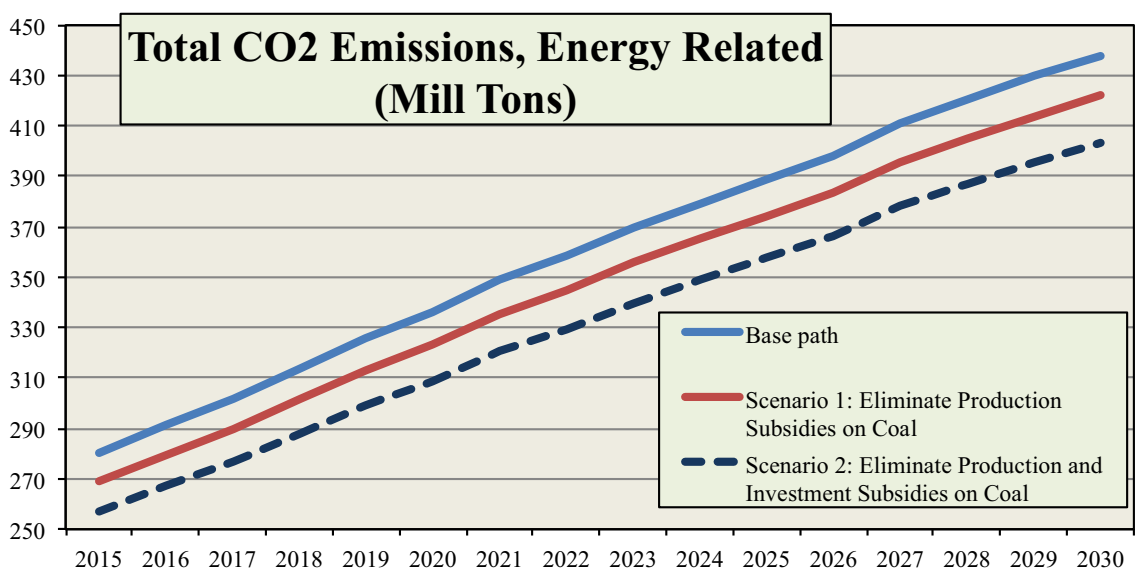

Fig. 3. Total $\mathrm{CO} 2$ emissions, energy related (mill tons).

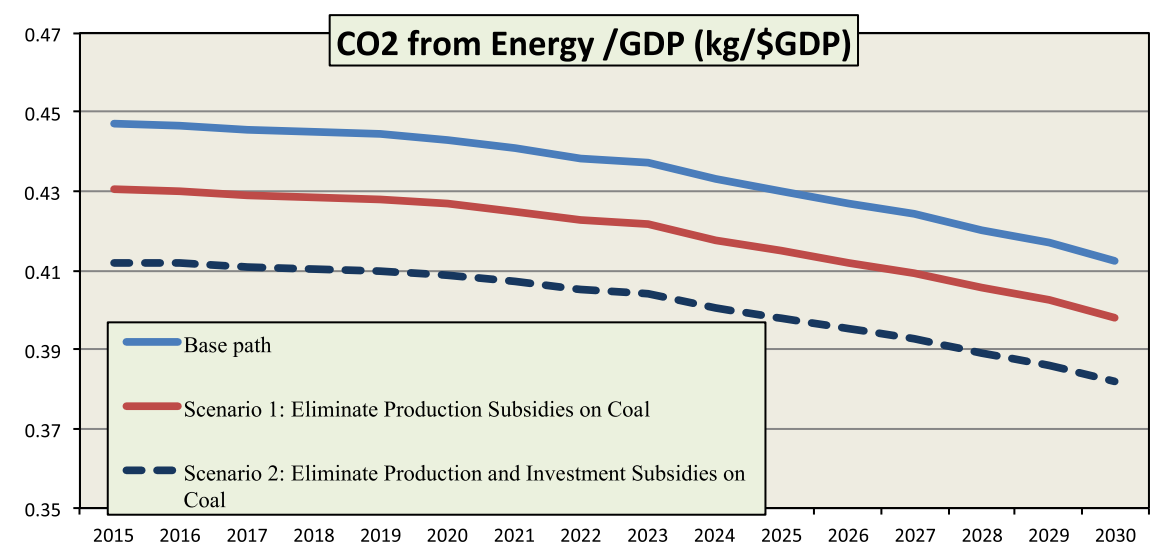

Fig. 4. $\mathrm{CO} 2$ from energy/GDP ( $\mathrm{kg} / \$ \mathrm{GDP})$.

On the other hand, while Turkey has ambitious plans for deployment of renewable energy, these are likely to be compromised by the continued existence of subsidies to coal-fired power generation and coal mining including the recently introduced regional development package with investment support and loan guarantees. Debate over subsidy reform is hindered by lack of transparent data in the magnitude and impacts of these subsidies. Since coal subsidies work against the competitiveness of renewable energy technologies, locks the energy sector in to the continuation of fossil-fuel-based systems, and jeopardizes investment decisions of renewable energy investors (Bridle and Kitson, 2014), elimination of coal subsidies and redirecting these funds towards renewable energy, green jobs, or $\mathrm{CO} 2$ mitigation in general will likely prove efficiency and social welfare improvement.

Apart from the ambitions to increase coal utilization in the country, Turkish environmental policies currently rely on gasoline and fuel taxes. However, the impacts and economic effects of the taxation/subsidization policies are not analytically investigated, and there is an acute need for development of such a framework. In fact, in the absence of any viable substitute energy sources, it is clear that polices based only on the fiscal motives of excise taxation will not suffice to achieve significant results for mitigation, 
and they ought to cover many other innovations of policy such as earmarking of the pollution tax monies and encouraging mitigation investment towards reduced energy intensities (Acar et al., 2014). Hence, there is a strong need for the construction and utilization of analytical models that can account for the general equilibrium effects for environmental policy analysis, especially under the discipline of dynamic general equilibrium. We believe that our model sheds light on the effectiveness of such policies and their potential impacts in the future.

As an extension of this work, viable policy alternatives can be put forward in order to help the greening of the economy. Coal subsidies could be transferred to the development of renewable energy and green jobs while the environmentally harmful impacts could be mitigated. Coal subsidy phase-out would decrease $\mathrm{CO} 2$ emissions, decrease the fiscal burden, and has the potential to generate green jobs and green energy. Switching from subsidization of coal to development of renewables promises a win-winwin strategy for a cleaner environment, for decreased dependence on fuel imports, and expansion of renewables. Besides, alternative public policy intervention mechanisms could be developed to accelerate technology adoption and achieve higher employment, energy security, and sustainable growth patterns.

\section{Acknowledgments}

Paper prepared for presentation at the 18th Annual Conference of the GTAP, Melbourne, June 2015. This study has been supported by a grant from the Turkish Sciences Association (TUBITAK) under Project no. 114K941. We are grateful, without implicating, to Ebru Voyvoda for her comments and suggestions, and to two anonymous reviewers of this journal for their diligent guidance and critiques.

\section{References}

Acar, S., Challe, S., Christopoulos, S., Christo, G., 2014. Fossil fuel subsidies as a loselose: fiscal and environmental burdens in Turkey. In: Paper Presented at the 14th IAEE European Energy Conference, October 28-31, 2014, Rome, Italy.

Acar, S., Kitson, L., Bridle, R., 2015. Subsidies to coal and renewable energy in Turkey. International Institute for Sustainable Development (IISD), Global Subsidies Initiative Report.

Aghion, P., 2014. Industrial policy for green growth. In: Paper presented at the 17th World Congress of the International Economics Association, Jordan.

Aghion, P., Boulanger, Julian, Cohen, Elie, 2011. Rethinking industrial policy. Bruegel
Policy Brief No 04, June.

Akin Olcum, Gokce, Yeldan, A. Erinc, 2013. Economic impact assessment of Turkey's post-Kyoto vision on emission trading. Energy Policy, 60(C), 764-774.

Armington, P. 1969 A theory of demand for products distinguished by place of production. IMF Staff Papers, vol. 16(1), pp. 159-178.

BNEF, 2014. Turkey's changing power markets - white paper. Bloomberg New Energy Finance.

Bohringer, C., Loeschel, A., 2006. Computable general equilibrium models for sustainability. Impact assessment: status quo and prospects. Ecol. Econ. 60 (1), 49-64.

Bouzaher, A., Sahin, S., Erinc Yeldan, A., 2015. How to go green? A general equilibrium investigation of environmental policies for sustained growth with an application to Turkey. Lett. Spat. Resour. Sci. 8 (1), 49-76.

Bridle, R., Kitson, L., 2014. The impact of fossil-fuel subsidies on renewable electricity generation. International Institute for Sustainable Development (IISD). Retrieved from 〈http://www.iisd.org/sites/default/files/publications/impact-fos sil-fuel-subsidies-renewable-electricity-generation.pdf).

Fraunhofer, ISE, 2013. Levelized Cost of Electricity-Renewable Energy Technologies. Study Edition, November 2013. Retrieved from 〈http://www.ise.fraunhofer. de/en/publications/studies/cost-of-electricity).

IEA, 2014. World Energy Outlook 2014. Retrieved from 〈http://www.iea.org/pub lications/freepublications/publication/KeyWorld2014.pdf $\rangle$.

Kumbaroglu, Selçuk G., 2003. Environmental taxation and economic effects: a computable general equilibrium analysis for Turkey. J. Policy Model. 25, $795-810$.

Lise, Wietze, 2006. Decomposition of CO2 emissions over 1980-2003 in Turkey. Energy Policy 34, 1841-1852.

OECD, 2014. Turkey: Economic Report. OECD Publications, Paris.

Sahin, S., 2004. An economic policy discussion of the GHG emission problem in Turkey from a sustainable development perspective within a regional general equilibrium model: TURCO (Unpublished PhD thesis). Université Paris I Panthéon, Sorbonne.

Stockholm Environment Institute, Climate Equity Reference Project, 〈http://clima teequityreference.org/calculator/ http://climateequityreference.org/calculator/ http://climateequityreference.org/calculator/ > (accessed 13.04.2015).

TEIAS, 2013. Electricity generation and transmission statistics of Turkey, 2013. Retrieved from 〈http://www.teias.gov.tr/T\%C3\%BCrkiyeElektrik\%C4\%BOstatis tikleri/istatistik2013/istatistik2013.htm 〉.

Telli, C., Voyvoda, E., Erinc Yeldan, A., 2008. Economics of environmental policy in Turkey: a general equilibrium investigation of the economic evaluation of sectoral emission reduction policies for climate change. J. Policy Model. 30 (1), 321-340.

UNFCCC, 2013. GHG Inventories (Annex I), National Inventory Submissions 2013. National Report for Turkey. Retrieved from 〈http://unfccc.int/national_reports/ annex_i_ghg inventories/national_inventories_submissions/items/8108.php〉.

Voyvoda, E., Yeldan, A. Erinc, 2011. Investigation of the Rational Steps Towards National Programme for Climate Change Mitigation (in Turkish). TR Ministry of Development, Ankara, mimeo.

Vural, B., 2009. General Equilibrium Modeling of Turkish Environmental Policy and the Kyoto Protocol (Unpublished MA thesis). Bilkent University.

WTO, 1994. Agreement on Subsidies and Countervailing Measures, Article 1. Uruguay Round Agreements.

Yeldan, A. Erinc, Taşçı, K., Voyvoda, E., Özsan, E., 2014. Planning for regional development: a general equilibrium analysis for Turkey. In: Yülek, M. (Ed.), Advances in General Equilibrium Modeling. Springer, Geneva, pp. 291-331.

Yeldan, A. Erinc, Taşçı, K., Voyvoda, E., Özsan, E., 2013. Escape from the middle income trap: which Turkey? TURKONFED, Istanbul (March). 